\title{
Invited review: Physiological and behavioral effects of heat stress in dairy cows
}

\author{
C. A. Becker, ${ }^{1}$ R. J. Collier, ${ }^{2}$ (-) and A. E. Stone ${ }^{1 *}$ (우 \\ ${ }^{1}$ Department of Animal and Dairy Science, Mississippi State University, Starkville, 39762 \\ ${ }^{2}$ Department of Animal and Veterinary Science, University of Idaho, Moscow 83844
}

\begin{abstract}
Animal welfare can be negatively affected when dairy cattle experience heat stress. Managing heat stress has become more of a challenge than ever before, due to the increasing number of production animals with increased milk yield, and therefore greater metabolic activity. Environmental temperatures have increased by $1.0^{\circ} \mathrm{C}$ since the $1800 \mathrm{~s}$ and are expected to continue to increase by another $1.5^{\circ} \mathrm{C}$ between 2030 and 2052 . Heat stress affects production, reproduction, nutrition, health, and welfare. Means exist to monitor and evaluate heat stress in dairy cattle, as well as different ways to abate heat, all with varying levels of effectiveness. This paper is a summary and compilation of information on dairy cattle heat stress over the years.

Key words: dairy, heat, temperature, abatement
\end{abstract}

\section{INTRODUCTION}

Heat stress is defined as the sum of internal and external forces that act on an animal to cause an increase in body temperature and evoke a physiological response (Yousef, 1985). Animal welfare can be negatively affected when dairy cattle experience heat stress. High external air temperature, humidity, and exposure to solar radiation can cause cattle to accumulate heat. During times of heat stress, dairy cattle attempt to maintain constant body temperature by regulating thermal energy balance (Fournel et al., 2017). To regulate thermal energy balance, the heat generated through metabolism (maintenance, exercise, growth, lactation, gestation, feed intake) must equal the heat lost to the environment. When the animal is unable to dissipate enough metabolically produced or absorbed heat, thermal balance cannot be maintained (Bernabucci et al., 2014).

Managing heat stress has become more of a challenge than ever before, due to the increasing number

Received November 18, 2019

Accepted March 15, 2020.

*Corresponding author: amanda.stone@msstate.edu of production animals with increased milk yield and therefore greater metabolic activity (Polsky and von Keyserlingk, 2017). Environmental temperatures have increased by $1.0^{\circ} \mathrm{C}$ since the $1800 \mathrm{~s}$ and are expected to continue to increase by another $1.5^{\circ} \mathrm{C}$ between 2030 and 2052 (IPCC, 2018). Specifically, the southeastern United States is subject to extended periods of hot weather with intense radiant energy and generally high relative humidity (West, 2003). Variable climate caused by global warming can contribute to sudden heat stress episodes. Sudden heat stress episodes can be especially difficult for dairy cattle to cope with because cows may require weeks to fully adapt to heat stress conditions (Perano et al., 2015). Based on an animal's previous experience with heat stress, including duration and intensity, physiological status of the animal, and environmental restraints, animals can alter their response to the stress both physiologically and behaviorally (Ratnakaran et al., 2017). When dairy cattle experience short bursts of heat stress, production is adversely affected for about a 5-d recovery period following the heat stress conditions (Ominski et al., 2002). Long-term exposure to high ambient temperatures and humidity can lead to carryover effects of heat stress. Decreased performance due to heat stress is generally associated with the summer months (June, July, and August); however, the negative consequences can continue into the autumn months (September, October, and November), even though cows may no longer be experiencing heat stress (Collier et al., 1981; Badinga et al., 1985; Wolfenson et al., 1997; De Rensis and Scaramuzzi, 2003). In regions with tropical and subtropical climates, such as the southeastern United States, the negative consequences of heat stress can start affecting dairy cows in spring months as well.

Heat stress can occur in all climate zones, depending on the time of year (Beede and Collier, 1986). Regions in Canada and the northern United States with temperate climates can be described as having short, warm summers, but cattle in these regions can still experience periods of heat stress (Polsky and von Keyserlingk, 2017). In these temperate regions, cows may not be 
physiologically adapted to heat stress conditions, making episodic thermal stress difficult for the animals to handle (Ominski et al., 2002). Multiple studies provide evidence that cows in temperate climates may be less acclimated to heat than cows in tropical, subtropical, and Mediterranean climates. This concept is illustrated by the production losses that cows experience at lower temperature-humidity index (THI) thresholds (Beede and Collier, 1986; Hammami et al., 2013; Schüller et al., 2014). However, dairy cows in tropical, subtropical, and Mediterranean climates experience extended periods of heat stress and are therefore unable to recover from the negative effects of heat stress as quickly as cows in temperate climates.

Regions located closer to the equator are more likely to experience climatic conditions that are conducive to heat stress, such as a longer hot season and higher relative humidity (Hahn and Osborn, 1969). The southeastern United States is classified as having a humid, subtropical climate (Johnson, 1987), where heat stress can persist for several months. In the state of Georgia, at least 138 d each year have a THI $>72$ (Ravagnolo et al., 2000). In Florida, dairy cows are considered to be in a constant state of heat stress during the full month of July (St-Pierre et al., 2003). Even in temperate Canadian summers, cows can experience about $50 \%$ of days in a state of heat stress (Ominski et al., 2002). Across the United States, dairy cows spend $14.1 \%$ of all annual hours in heat stress conditions (El-Tarabany and El-Bayoumi, 2015).

In subtropical climate zones, little to no alleviation from heat occurs at night (Johnson, 1987). In the past 100 years in the United States, the annual mean diurnal temperature range, changes in daily maximum and minimum temperatures, has steadily decreased, especially in summer and fall months (Qu et al., 2014). Typically, ambient temperature is warmer during the day, when solar radiation is present, and will begin to decrease at night when the sun sets. However, over the last 50 years, large increases in daily minimum temperature have occurred, leading to decreased average diurnal temperature ranges (Braganza et al., 2004). Diurnal temperature range is an important indicator of climate change and plays an essential role in heat stress.

Due to ruminants being diurnally active (active during daylight hours with a period of sleeping or inactivity at night), a greater amount of heat is produced throughout the day compared with the night (Veissier et al., 2017). Ruminant animals also spend more time feeding and standing from dusk to dawn in confinement settings (Yamomoto et al., 1979). Following a feeding, ruminal fermentation and nutrient absorption in the lower digestive tract take place, causing a large amount of metabolic heat to accumulate (Ando et al., 1997; Sunagawa et al., 2015). When ambient temperature and humidity do not decrease enough at night compared with the day, dairy cattle are unable to lose heat that was gained throughout the day, causing these animals to be in a constant state of heat stress.

Dairy cattle display maximum genetic potential with minimal physiological costs and maximum productivity only within their thermal neutral zone (TNZ; Folk, 1974; Tao et al., 2018). The TNZ is a narrow temperature range when the animal does not have to expend energy to maintain normal body temperature. Cattle are able to regulate body temperature within an upper critical temperature and a lower critical temperature. A lactating dairy cow's TNZ is in the range of 5 to $25^{\circ} \mathrm{C}$ (Figure 1; Kadzere et al., 2002). When a dairy cow's upper critical temperature is attained, she is unable to effectively regulate her internal body temperature, heat stress is induced, and health, productivity, and behavior are dramatically altered (Kadzere et al., 2002; West, 2003; Hansen, 2013; Tao et al., 2018). Factors that can influence TNZ include age, breed, production, body condition, stage of lactation, pregnancy, housing, type of hair coat, and skin pigmentation of hide and hair (Yousef, 1985).

High-producing dairy cattle have increased sensitivity to heat stress, compared with lower-producing cows (Kadzere et al., 2002; Kumar et al., 2011). Genetic selection for milk production traits contributes to cows producing an increased amount of metabolic heat. Cows with greater milk production potential have greater feed intake, and thus higher metabolic heat production through processes such as body tissue synthesis and milk secretion, than their counterparts of lower genetic caliber (Kadzere et al., 2002; Collier et al., 2012). Throughout the past decade, US milk production has increased by $13 \%$, from nearly 9,000 to $10,400 \mathrm{~kg} /$ cow yearly (USDA, 2018). With an increase in milk yield from 35 to $45 \mathrm{~kg} / \mathrm{d}$, the heat stress temperature threshold may be decreased by $5^{\circ} \mathrm{C}$ (Berman, 2005), meaning that cows will become heat stressed earlier.

Holstein cows are not well adapted to the excessive thermal stress that is experienced in the southeastern United States. Cattle with dark coats absorb more solar radiation compared with cows that have lightercolored coats (Finch and Western, 1977; da Silva et al., 2003; Maia et al., 2005). Few specific genes have been targeted to improve heat tolerance. The slick hair gene, which controls hair length, was originally identified in Carora cattle (Olson et al., 2003) but has since been introduced to Holsteins through crossbreeding. Cattle with the slick hair gene will have a very short, sleek coat that can appear glossy (Dikmen et al., 2008). Cattle with the slick hair gene have displayed greater 
heat tolerance with lower body temperatures in heat stress conditions compared with their contemporaries with the wild-type hair (Olson et al., 2003).

Cows can dissipate heat through conduction, convection, radiation, and evaporation. But how effective these heat dissipation methods are is dependent on the temperature difference between the cow and the surrounding environment (Gebremedhin, 1985). Evaporative cooling mechanisms (sweating and panting) occur with greater environmental temperature, whereas nonevaporative cooling mechanisms (conduction, convection, radiation) occur with milder temperatures (Berman et al., 1985). Conduction works through physical contact with surrounding objects. If an object, such as the ground, is cooler than the surrounding environment, the heat from the cow will flow through conduction to the cooler object (Atrian and Shahryar, 2012). Heat dissipation via convection occurs when the surrounding hot air is replaced with a layer of cooler air near the surface of the skin. When environmental temperature is lower than body temperature, cattle can transfer the heat produced to the surrounding environment via radiation. Dissipating heat through radiation and convection does not require energy expenditure. As environmental temperatures increase further, evaporative cooling occurs. With evaporative heat loss, panting and sweating occur. About $15 \%$ of accumulated metabolic heat is used by the respiratory tract for evaporative heat loss (Kadzere et al., 2002). Evaporative cooling occurs when sweat or moisture is evaporated from the skin or respiratory tract (Atrian and Shahryar, 2012). Dissipating heat through evaporation requires the animal to expend energy (Kadzere et al., 2002). In regions with hot, dry climates, evaporative cooling from the surface of the skin is most effective. In regions with a subtropical climate, the high relative humidity limits the rate of heat loss via evaporative cooling (Silva et al., 2007). However, when natural heat dissipation methods become insufficient, due to an increase in environmental temperature, the increased heat load can increase body temperature (Wheelock et al., 2010) and decrease milk yield (Wheelock et al., 2010) and fertility (De Rensis and Scaramuzzi, 2003), and, in extreme cases, can result in mortality (Stull et al., 2008; Vitali et al., 2009).

\section{EFFECTS OF HEAT STRESS ON PERFORMANCE}

\section{Reproduction}

The negative consequences of heat stress on the reproductive performance of dairy cattle are well

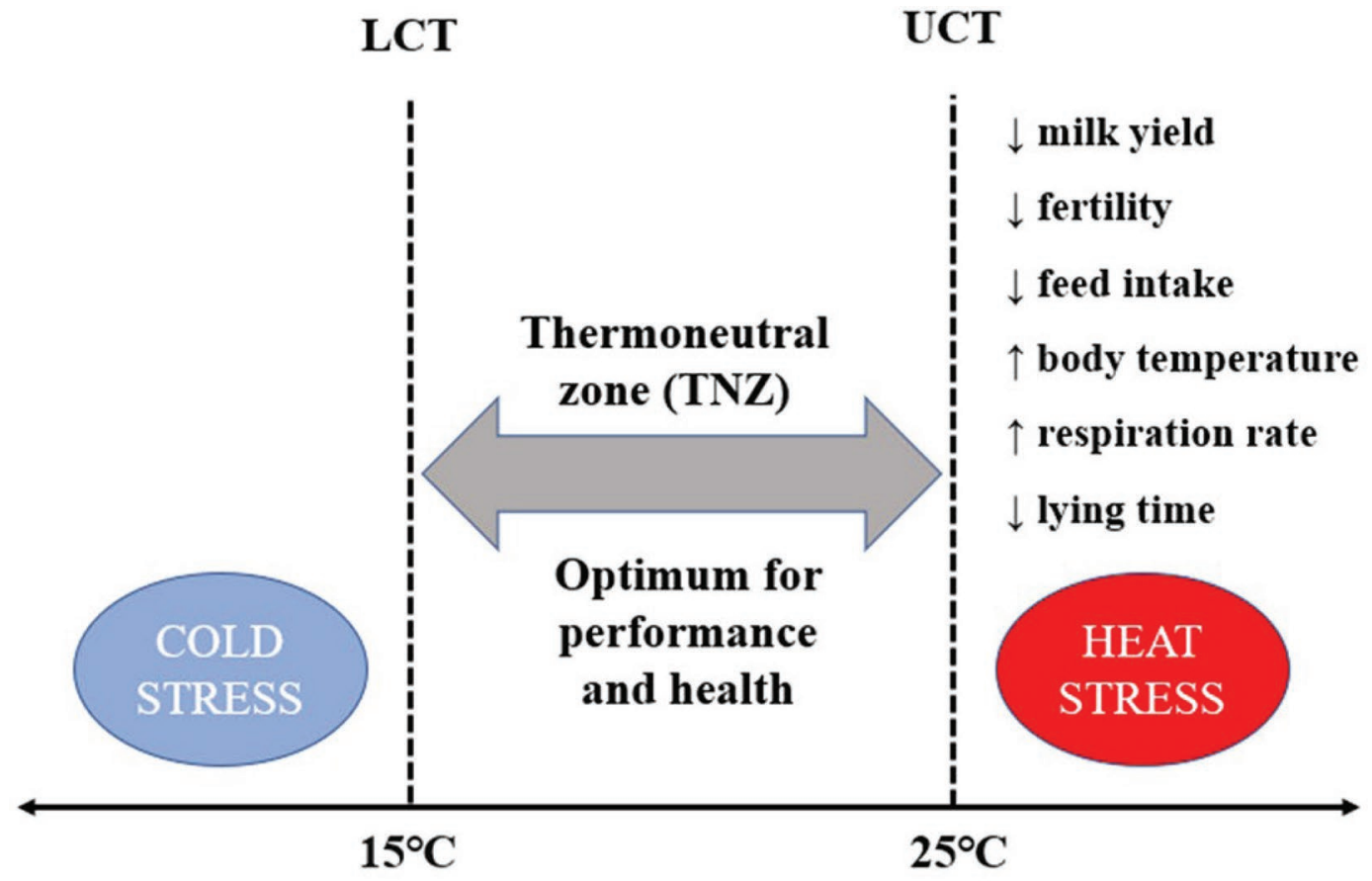

\section{Ambient temperature}

Figure 1. Thermoneutral zone (TNZ), lower critical temperature (LCT), and upper critical temperature (UCT) of a lactating dairy cow (modified from Kadzere et al., 2002). 
documented. Heat stress may alter duration of estrus (Gangwar et al., 1965), uterine function (Collier et al., 1982), endocrine status (Collier et al., 1982; Wise et al., 1988; Wolfenson et al., 1988b; Howell et al., 1994), follicular growth and development (Wilson et al., 1998), and luteolytic mechanisms (Wilson et al., 1998). Extended periods of heat stress can also affect early embryonic development and survival (Biggers et al., 1987; Wolfenson et al., 2000; De Rensis and Scaramuzzi, 2003), fetal growth (Wolfenson et al., 1988a), and colostrum quality (Nardone et al., 1997). Dairy cattle fertility is influenced by multiple factors, such as nutrition, hormone level, management, and environment, although environmental factors contribute the most influence (Dash et al., 2016).

Conception rate is defined as the number of pregnant cows divided by the total number of services, multiplied by 100 (Schüller et al., 2014). Over the past 60 years, conception rate has decreased in high-producing cows from 55 to $35 \%$ (Schüller et al., 2014). This decline is likely related to physiological changes (Wiltbank et al., 2006), changes in management, and increasing milk production (Honig et al., 2016). During periods of heat stress, conception rates decrease further below 35\%, compared with periods without heat stress (De Rensis et al., 2002; De Rensis and Scaramuzzi, 2003; Schüller et al., 2014). García-Ispiearto et al. (2007) found a decrease of up to $23 \%$ in conception rate for heatstressed cows compared with non-heat-stressed cows. Conception rates of dairy cows is negatively affected by extended periods of heat stress, as well as single days of heat stress near the day of breeding (Morton et al., 2007; Schüller et al., 2014). Pereira et al. (2013) measured rectal temperature during artificial insemination of cows and found that rectal temperatures greater than $39.1^{\circ} \mathrm{C}$ caused conception rates to significantly drop from 21 to $15 \%$.

Estrus is expressed by a period of high activity ranging from 10 to $12 \mathrm{~h}$. Approximately $19.4 \pm 4.4 \mathrm{~h}$ after the end of the period of high activity is when ovulation occurs and breeding should take place (De Rensis et al., 2015; Silper et al., 2015). A cow's ability to display natural mating behavior is negatively affected by increased environmental temperatures that can cause physical lethargy and reduce the duration and intensity of estrous expression (Orihuela, 2000). Dransfield et al. (1998) reported that the number of mounts in warm months was almost 50\% lower compared with cool months. The reduced estrous expression may be a heat stress coping mechanism to prevent further increase of internal heat production than that already caused by other estrus-related activities (Hansen and Aréchiga, 1999). When estrous expression and detection is de- creased, this can lead to fewer cows being inseminated and insemination at the wrong time, contributing to a decrease in farm profitability (De Rensis and Scaramuzzi, 2003). Future research using precision dairy technologies to monitor cow activity and track estrus behaviors should be conducted to bridge the gap of knowledge regarding the negative effects of heat stress on reproductive performance.

Reproductive inadequacies such as decreased conception rate in summer months have contributed to producers altering management practices. Timed AI protocols are used to reduce the necessity of visual estrus detection and to increase pregnancy rates (Collier et al., 2006). Increased conception rates have been observed from timed AI but are still not as high in summer months compared with winter months (Edwards and Hansen, 1997). Seasonal breeding can be practiced by producers in hot climates to avoid breeding and calving during summer months. Ray (1991) reported that cows calving in the spring or summer had the longest calving interval and the most services per conception. Thermal stress in cows 1 to $2 \mathrm{~d}$ before AI and during early pregnancy can be detrimental to fertility. Researchers report that heat stress $2 \mathrm{~d}$ before AI (Ingraham et al., 1974), the day of AI (Cavestany et al., 1985), and $1 \mathrm{~d}$ after AI (Gwazdauskas et al., 1975) are negatively correlated with conception rates. In an Australian study, cows experiencing heat stress 3 to 5 wk before and 1 wk after the day of service had decreased conception rates (Morton et al., 2007). In another study, researchers set a THI threshold of 73 at which conception rate is negatively affected. On the day of breeding, cows that were exposed to $\geq 9 \mathrm{~h}$ of a THI of 73 had a $26 \%$ decrease in conception rate compared with cows exposed to a THI of 73 for $<9 \mathrm{~h}$. The researchers concluded that exposure to heat stress 3 wk before the day of service can negatively affect conception rates (Schüller et al., 2014).

Reduced reproductive performance during summer and autumn months has contributed to an important economic loss to the dairy industry (Collier et al., 2006). The economic loss is largely influenced by increased calving intervals and increased culling rates (Lee and Kim, 2007). St-Pierre et al. (2003) reported that with only minimal heat abatement available (randomly planted shade trees) economic losses would be large in regions with high temperatures and humidity that lasts for several months each year. In Kentucky, when dairy cows are exposed to $21 \%$ of annual hours in heat stress conditions, average days open increased by $27 \mathrm{~d}$ compared with cows in periods without heat stress. The increase in days open leads to a $2.7 \%$ increase in reproductive culling. This contributed to an 
economic loss of $\$ 285 /$ cow per year. In Florida, average days open increased by $59 \mathrm{~d}$ with an $8.0 \%$ increase in reproductive culling when cows were experiencing $49 \%$ of annual hours in heat stress conditions compared with periods without heat stress. This contributed to an economic loss of $\$ 676 /$ cow per year (St-Pierre et al., 2003). Overall, reduced reproductive performance in periods of heat stress contributes to a large economic loss to the dairy industry.

\section{Nutrition}

At any production level, dairy cattle will show an inverse relationship between milk yield and heat stress (Ravagnolo et al., 2000; West, 2003). However, multiparous cows and cows with greater milk yields are more sensitive to the effects of heat stress compared with lower-producing or primiparous cows (Yousef, 1985). Lactating dairy cows need to eat large amounts of feed to sustain high milk yields (West, 2003). With the appetite loss caused by heat stress conditions, meeting the energy demands of a high-producing cow is a challenge (Bernabucci et al., 2014). In addition, mild to severe heat stress can increase metabolic maintenance requirements by 7 to $25 \%$ (NRC, 2001). With decreased energy availability due to reduced feed intake, along with increased maintenance costs, heat-stressed lactating cows can go into a state of negative energy balance (Moore et al., 2005; Settivari et al., 2007; Rhoads et al., 2009; Shwartz et al., 2009). The negative energy balance that may occur in heat-stressed cows is similar to the negative energy balance experienced by cows in early lactation, but not to the same degree. Early postpartum negative energy balance is followed by an increased risk of metabolic disorders and health issues, and decreased reproductive performance (Drackley, 1999). Bernabucci et al. (2014) speculated that the negative production, health, and reproduction effects experienced by cows during heat stress may be mediated by negative energy balance. The current research is unclear whether the decreased production and performance occur directly from heat stress or indirectly from reduced feed intake.

Many physiological responses to heat stress are strategies aimed at maintaining core body temperature (Collier et al., 1982). In periods of heat stress, the amount of heat production and heat accumulation leads to an inability to effectively dissipate the heat gained. The heat load may increase to the point that body temperature will increase, DMI will decrease, and therefore production will decrease in an attempt to maintain homeostasis (West, 2003). Higher-producing cows have a lower temperature threshold when milk loss begins to occur, due to their greater metabolic heat production
(Berman, 2005). Purwanto et al. (1990) found that the amount of heat produced by lactating cows that yielded 18.5 and $31.6 \mathrm{~kg} / \mathrm{d}$ of milk was 27.3 and $48.5 \%$ greater compared with nonlactating cows.

At air temperatures of 25 to $26^{\circ} \mathrm{C}$, the first step to decrease heat production in dairy cows is reduction of DMI (Baumgard and Rhoads, 2013). Hypophagia, or reduction in feed intake, occurs from the cooling center of the hypothalamus signaling the medial satiety center to inhibit the appetite center from functioning properly (Albright and Alliston, 1971). Therefore, insufficient nutrients are available for the mammary gland to produce large amounts of milk (West, 2003; Rhoads et al., 2009). Bouraoui et al. (2002) found that cows experiencing heat stress decreased DMI by $9.6 \%$ compared with cows in the TNZ. In a study conducted by Spiers et al. (2004), exposure to heat stress reduced DMI by $14.6 \mathrm{~kg} / \mathrm{cow}$ daily and milk yield by $11.8 \mathrm{~kg} / \mathrm{cow}$ per day compared with cows in the TNZ. However, more research needs to be performed to understand how reduced DMI during periods of heat stress can affect the physiological and behavioral responses of a lactating dairy cow.

The reduced feed intake from heat stress has been primarily associated with the decrease in milk yield (Fuquay, 1981; Collier et al., 1982; West, 2003). However, Rhoads et al. (2009) found that only about $50 \%$ of the milk yield decrease from heat stress comes from reduced nutrient intake, indicating that the decrease in milk production can be affeced by changes not associated with energy intake. Nutrient partitioning may account for a large portion of the direct effects of heat stress (Rhoads et al., 2009). When the metabolic profile of a heat-stressed cow is compared with that of a non-heat-stressed cow on a diet equivalent in energy intake, a difference in fatty acid concentration is exhibited (Shwartz et al., 2009). Lactating cows on a poorer plane of nutrition typically have increased plasma fatty acid levels compared with cows on a higher plane of nutrition (Bauman et al., 1988). To support milk production, animals on a poor plane of nutrition will utilize increased plasma fatty acid as a glucose-sparing mechanism to maximize milk production. Rhoads et al. (2009) found that heat-stressed cows did not display this glucose-sparing mechanism (they did not mobilize adipose tissue) even though they had a decreased feed intake. In studies conducted by Rhoads et al. (2009) and Wheelock et al. (2008, 2010), reduced DMI from heat stress caused cows to have a $45 \%$ decrease in milk yield compared with pair-fed cows in a thermal neutral environment, with only a $19 \%$ decrease in milk yield (Wheelock et al., 2008, 2010; Rhoads et al., 2009). These results may indicate that heat stress directly af- 
fects how energy is distributed throughout the body (Rhoads et al., 2009; Wheelock et al., 2010). Past researchers have focused on studying heat stress and its effect on DMI in confinement settings. Studying heat stress in grazing cattle and how feed intake and grazing behaviors are altered could be beneficial.

To increase milk production in summer months, many researchers have conducted studies focused on altering management practices such as ration changes and feeding at different times of the day. Adding fat or ionophores to the ration has been used to increase milk production in times of heat stress. Bauman et al. (2008) stated that feeding fat to high-producing dairy cows resulted in an increase in milk yield during hot conditions. When feeding ionophores in times of heat stress, the production of propionate will increase, which may enhance energy efficiency (Russell and Strobel, 1989), although due to the decreased DMI, any extra energy gained by the fat or ionophores may be offset. Diets that contain large amounts of concentrates increase the risk of ruminal acidosis, which can further contribute to decreased appetite and reduced DMI (Baumgard and Rhoads, 2013). Fat levels in the diet should not exceed 5 to $7 \%$. For cows to receive the maximum benefits of the dietary addition of fat, modifications to the environment should be implemented through the provision of shade, fans, cooling with water, or any combination of the 3 cooling strategies (Huber et al., 1994; West et al., 1999).

Water is considered the most important nutrient for health and performance in dairy herds (NRC, 2001) due to the large amount of milk dairy cows produce. Access to fresh water is important for dairy cattle in all environments but especially during periods of heat stress (Polsky and von Keyserlingk, 2017). Water is necessary for basic health functions such as digestion and metabolism of energy and nutrients, transport of nutrients and metabolites to and from cells in blood, excretion of waste products (via urine, feces, and respiration), and maintenance of balanced ion, fluid, and heat balance, and contributes to the developing fetal environment (Houpt, 1984; Murphy, 1992).

Increased water intake is a major physiological reaction to heat stress (Johnson and Yeck, 1964; McDowell, 1972). In hot environments, cows will increase water intake to make up for the water lost through sweat, respiratory evaporation, feces, and milk (Hoffman and Self, 1972; Shultz, 1984; Richards, 1985; Holter and Urban, 1992). When the environmental temperature exceeds the TNZ, water intake can increase by 1.2 to 2 $\mathrm{kg}$ per degree Celsius (West, 2003). When water intake is low, animal performance, health, and behavior are altered (Cardot et al., 2008). Potential negative effects of low water intake include increases in hematocrit and blood urea (Steiger Burgos et al., 2001) and decreased respiration rate and rumen contractions (Little et al., 1980; Steiger Burgos et al., 2001), and can provoke aggressive behaviors around the waterers (Little et al., 1980). Hoffman and Self (1972) studied the effect of season on water intake in feedlot steers when shade was provided compared with steers with no shade. Steers' water intake was increased in the summer compared with the winter. In their study, providing shade in hot environmental temperatures was beneficial. Steers consumed less water when shade was provided, meaning that the cattle with shade were cooler, resulting in less body water loss. More studies should be conducted focusing on water intake and its effect on milk production and behavior around water troughs during periods of heat stress, using different heat abatement strategies.

\section{Milk Production}

With the advances in nutrition, technology and biotechnology, and genetic progress, milk production in the United States has increased by $12 \%$ per cow over the past decade (USDA, 2018). As advances in the industry continue to focus on increased milk production, heat stress will become an increasingly relevant concern (Wheelock et al., 2010). In order for cows to meet their genetic potential during times of heat stress, improved management practices are essential.

Dairy cows in the southeastern United States spend nearly $50 \%$ of all annual hours under thermal stress, which can lead to a loss of milk production of up to $2,072 \mathrm{~kg} / \mathrm{cow}$ yearly (St-Pierre et al., 2003). Somatic cell count peaks during summer months, which may indicate increased cases of mastitis (Lievaart et al., 2007). Tao et al. (2018) reported that Georgia dairy herds that participated in DHIA monthly milk testing exhibited a decrease in milk yield per cow, and SCC increased as average daily THI increased. All of these losses contribute to a seasonality of milk production in the southeastern United States and results in economic burdens on dairy producers (St-Pierre et al., 2003). The decrease in milk production from heat stress alone contributes to a $\$ 1.2$ billion annual profit loss for the entire US dairy sector (Key et al., 2014). Increased SCC in summer months compared with winter months contributes to the seasonal trends in milk production. St-Pierre et al. (2003) estimated milk losses from 436 $\mathrm{kg}$ to $1,233 \mathrm{~kg} / \mathrm{cow}$ per year in the southeastern United States. In addition, results from a Florida study revealed a $15 \%$ reduction in milk yield in summer months compared with winter months (De Vries and Risco, 2005). When cows are under heat stress, herd SCC and 
clinical mastitis infection rate may increase, furthering the decrease in production (de Haas et al., 2002).

For beneficial cooling, such as shade or sprinklers, to be implemented and to minimize economic production losses, producers need to be aware immediately when heat stress occurs. A lag time between environmental events and the effect on cow performance has been exhibited (West, 2003). In a Florida study, black globe temperature (a measure of ambient temperature and radiant energy) had no significant effect on milk production when measured on the same day (Collier et al., 1981). The effects of a given black globe temperature on milk production are most noticeable between 24 and 48 $\mathrm{h}$ following the heat stress period (Collier et al., 1981; Spiers et al., 2004). West et al. (2003) reported that mean THI had the greatest correlation to decreases in milk production $2 \mathrm{~d}$ before milk yield measurement. For each unit increase of THI, Holstein cows decreased milk production by $0.88 \mathrm{~kg}$ for the 2 -d lag of mean THI. When milk yield was measured on the same day as THI, the decrease in production was substantially less compared with 2 d earlier.

Stage of lactation plays an important role in the severity of heat stress and the amount of milk lost (Tao et al., 2018). Up to $60 \mathrm{~d}$ postpartum, the cow is in a negative energy balance, and to make up for the excess energy loss, body stores are mobilized. Due to increased metabolic heat, the first $60 \mathrm{~d}$ in milk and at peak lactation are critical for managing heat stress to minimize effects on milk production (Sharma et al., 1983).

Season of calving can also contribute to a decrease in milk production. In Florida, some producers seasonally calve their herds in fall and winter months to avoid cows starting or being in peak lactation during summer months (De Vries and Risco, 2005). Producers use this strategy with the goal of minimizing overall milk loss (Ferreira and De Vries, 2015).

\section{Milk Components}

Dairy cows experiencing heat stress can have altered milk composition. Some researchers have found heat stress to be associated with a decrease in total protein and total fat yield (Bouraoui et al., 2002; Bernabucci et al., 2015; Hammami et al., 2015; Hill and Wall, 2015). Tao et al. (2018) explained that milk component yields may be altered simply due to the decrease in milk volume experienced in summer months. However, the effects of heat stress on percentages of milk fat and protein are inconsistent (Regan and Richardson, 1938; Moody et al., 1967; Maust et al., 1972). Cows subjected to heat stress can have $9.7 \%$ less milk fat (Maust et al., 1972), and milk protein and nonfat sol- ids may also decrease (Regan and Richardson, 1938; Moody et al., 1967; Coppock, 1978; Arieli et al., 2004; Rejeb et al., 2012). Data on the changes of protein and fat content as a result of heat stress vary, with authors reporting either a reduction, an increase, or no change in components (Roman-Ponce et al., 1977; Knapp and Grummer, 1991; Lacetera et al., 2003).

Abeni et al. (1993) reported that when THI increased above 75 , lower values of milk fat were found. When THI was less than 75 , milk fat content averaged 3.46 $\mathrm{g} / 100 \mathrm{~g}$, whereas when THI was 75 or greater, milk fat content averaged $3.17 \mathrm{~g} / 100 \mathrm{~g}$. Results from Bernabucci et al. (2015) are in agreement with those of Abeni et al. (1993), with a marked reduction of milk fat during summer months compared with winter and spring months (3.2 g/100 g, vs. $3.8 \mathrm{~g} / 100 \mathrm{~g}$, vs. 3.61 $\mathrm{g} / 100 \mathrm{~g})$. However, other researchers found no differences between milk fat content and seasons (Cowley et al., 2015; Hammami et al., 2015). When comparing the effects of heat stress on milk components in Holstein and Jersey cows, the percent of milk fat increased for heat-stressed Holsteins from 3.3 to $3.7 \%$, but no change in milk fat percent $(4.6 \%)$ occurred for heat-stressed Jersey cows. The researchers stated that the differences exhibited could be due to a difference in stage of lactation, diet, or heat abatement, and could indicate a breed difference in milk fat percentage in response to heat stress (Smith et al., 2013). In one study, researchers categorized monthly THI into groups (low THI was less than 70 , and high THI was 80 to 85 ) and compared milk fat percent between the 2 groups. Milk fat percent decreased in the low group compared with the high group from 3.91 to $3.74 \%$, respectively (Nasr and ElTarabany, 2017).

Milk protein percent changes associated with heat stress are also inconsistent. Results from some studies show that cows had lower protein percent in summer months compared with winter months (Smith et al., 2013; Bernabucci et al., 2015), whereas others show no difference in protein percent between the 2 seasons (Hammami et al., 2015). Abeni et al. (1993) found that cows experiencing a THI greater than 75 had a decrease in protein content of $2.89 \mathrm{~g} / 100 \mathrm{~g}$, compared with cows experiencing a THI less than 75, with $3.02 \mathrm{~g} / 100 \mathrm{~g}$. Cowley et al. (2015) stated that cows exposed to heat stress had a decreased milk protein content compared with cows in thermoneutral conditions. When cows were fed on the same plane of nutrition and were not subjected to heat stress, milk protein showed intermediate values compared with cows experiencing heat stress (Cowley et al., 2015). These results are in agreement with others that performed pair-fed experiments (Rhoads et al., 2009; Wheelock et al., 2010) and may 
indicate that the decrease in protein content is related to a direct effect of heat stress instead of a reduction in feed intake (Summer et al., 2018). The researchers explained that the downregulation of mammary protein synthesis could be the result of the milk protein decline due to heat stress.

The mechanisms involved in the reduction of milk protein yield due to heat stress remain largely unknown but are likely attributable to multiple biological systems. In a study by Gao et al. (2017), cows under heat stress had reduced milk yield by $17 \%$, milk protein by $4.1 \%$, and $4 \%$ fat-corrected milk by $23 \%$ compared with pair-fed thermoneutral cows. Heat-stressed cows in this study had a decrease in plasma glucose and fatty acid concentration. The researchers concluded that cows under heat stress may have an increased utilization of systemic amino acids, limiting the amino acid supply to the mammary gland for milk protein synthesis (Gao et al., 2017). Alterations in the somatotropic axis that plays a key role in the regulation of metabolism and physiological processes during heat stress may also explain a small portion of the decrease in milk protein yield (Rhoads et al., 2009). Additionally, blood flow to the mammary gland reduces the protein precursor supply and nutrient partitioning available to the mammary gland when heat stress is induced and, in turn, alters protein synthesis (Lough et al., 1990; Gao et al., 2017).

After water, lactose is the main component of milk (Summer et al., 2018). Abeni et al. (1993) demonstrated that when comparing heat-stressed cows (THI $>75)$ to non-heat-stressed cows (THI <75), lactose content was not significantly different between the 2 treatments (5.06 vs. 5.10). Cowley et al. (2015) confirmed these results in a more recent experiment.

Variability in the results of studies looking at the effects of heat stress on milk fat and protein content could indicate that the differences exhibited are influenced by other factors, such as diet, stage of lactation, level of heat stress, experimental model used, cooling facilities, and length of treatments (Tao et al., 2018). Further research is needed in this area to confirm the many speculations on the cause of the alterations of milk fat and protein contents due to heat stress.

\section{Health}

Innate immune function may be suppressed in lactating cows during heat stress, which can lead to an increase in risk of clinical diseases such as mastitis and metritis (Steele, 2016). The innate immune system is the primary defense mechanism for animals to protect against and cope with environmental stressors (Das et al., 2016). Immunity indicators, such as cytokine production, proliferation of immune cells, migration of lymphocytes to the udder, and cell viability, were all decreased due to heat stress (Steele, 2016). Heatstressed cattle have displayed an increased white blood cell count by 21 to $26 \%$ (Das et al., 2016). The ratio of white blood cells may also be altered in response to increasing THI. Muñoz et al. (2014) found that the neutrophil-to-lymphocyte ratio, a marker for inflammation and infection, was significantly increased during summer months.

Hyperthermia promotes oxidative stress, which may be attributed to an increased formation of reactive oxygen species (Flanagan et al., 1998). Pahlavani and Harris (1998) demonstrated in an in vitro study that an increased generation of oxygen free radicals during periods of heat stress may be associated with inhibition of proliferation of T-cells or lymphocytes. Researchers stated that heat stress greatly inhibited the activity of the interleukin-2 gene, which plays a crucial role in $\mathrm{T}$ cell proliferation. T-cells are processed by the thymus gland and are an essential part of the immune response. Therefore, when experiencing heat stress, the immune response of cattle is weakened (Brenu et al., 2013).

Due to the downregulation of the immune response in periods of heat stress, disease occurrence may be increased, including diseases such as liver lipidosis, lameness, metritis, and mastitis (Basiricò et al., 2009; Jingar et al., 2014). In vitro studies indicate that primary bovine mammary epithelial cells display greater risks of programmed cell death when exposed to high ambient temperatures (Li et al., 2015; Tao et al., 2018). The decrease in the total number of mammary epithelial cells may partially explain the decrease in milk yield seen in lactating cows experiencing heat stress (Tao et al., 2018).

An increased risk for mastitis has also been associated with periods of hot weather, leading to a further decrease in milk yield (Giesecke, 1985; Morse et al., 1988; Waage et al., 1998). Somatic cell count is the number of leukocytes per milliliter of milk and is a common indicator of milk quality. Somatic cell count is used as a marker for intensity of the mammary inflammatory response (Bertocchi et al., 2014). White blood cells, specifically polymorphonuclear neutrophil leukocytes, are the main source of the increase in somatic cells during a period of inflammation. Polymorphonuclear neutrophils are a key defense mechanism in the udder, engulfing foreign mastitis-causing bacteria (Dosogne et al., 2002). Infection status is the main factor contributing to an increase in SCC, but other variables play a smaller role, such as age and stage of lactation (Harmon, 1994). Somatic cell count tends to increase as a cow ages or progresses further into her lactation, 


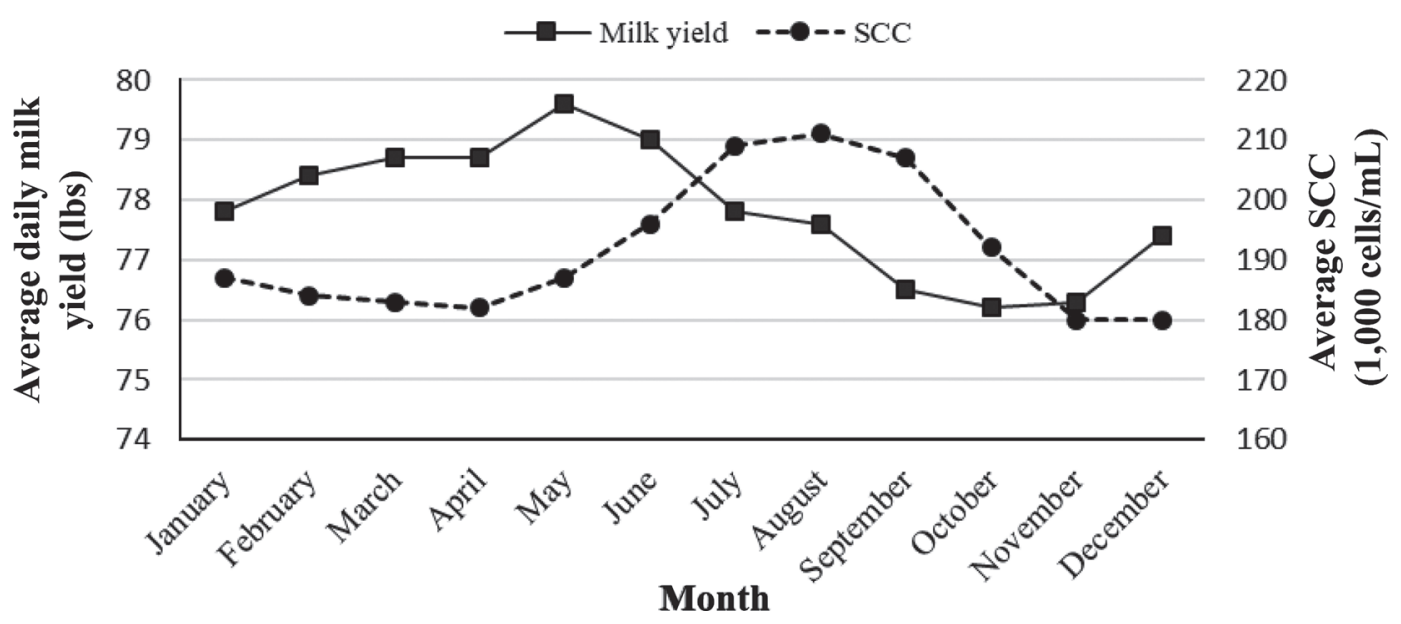

Figure 2. Characteristics of test-day milk yield and SCC from DHI herds in the United States during 2018 by month (reproduced from Norman et al., 2019).

with heat stress further contributing to the increase in SCC for these animals. However, if the mammary gland is healthy, SCC tends to decrease rapidly after calving, and age affects are minimal (Dosogne et al., 2002).

Somatic cell count often follows a seasonal pattern, with an increase in the summer and a decrease in the winter (Schukken et al., 1993; Olde Riekerink et al., 2007; Archer et al., 2013). Figure 2 displays the monthly trend of test-day milk yield and SCC from US farms enrolled in the DHI program for 2018.

In a Canadian study, 48 to $71 \%$ of herds experienced an increase in herd SCC from July to October (Sargeant et al., 1998); $26 \%$ of these herds experienced summer herd SCC increases in more than $75 \%$ of their years of operation, and $71 \%$ of herds experienced herd SCC increases in more than $50 \%$ of their years of operation (Shock et al., 2015). Igono et al. (1987) explained that milk production and SCC are inversely related. Ferreira and De Vries (2015) stated that a dilution effect of herd SCC in relation to milk volume may occur, which may partly explain the increase in herd SCC during summer months.

Increased risk of infection during heat stress may be explained by depressed immune function (do Amaral et al., 2011; Hammami et al., 2013) or from the increased pathogen load in the cows' environment (Godden et al., 2003). Dhakal et al. (2013) reported that dairy producers in Nepal in regions with hot environmental temperatures ranked problems with increased incidence of external parasites the highest. Increase in THI can result in an increased risk for mastitis due to high temperatures facilitating survival and multiplication of pathogens (Das et al., 2016). Escherichia coli thrives in temperatures ranging from 19.3 to $44.5^{\circ} \mathrm{C}$, and Klebsiella pneumonia thrives in temperatures ranging from
22.7 to $41.0^{\circ} \mathrm{C}$ (Raghubeer and Matches, 1990). These bacteria are able to survive in high ambient temperatures but are unable to survive in colder months. In one study, researchers found that coliform counts in bedding were lowest in winter and highest in summer in all the housing areas studied (freestalls, tiestalls, and maternity barns). Freestall housing had significantly higher coliform counts in summer months compared with all other seasons. The bedding had an increased pathogen load, meaning that the teat ends of cows lying on that bedding were associated with an increased rate of coliform intramammary infection during the summer (Smith et al., 1985). Dairy herds that were kept on pasture had an increased risk of mastitis infections caused by Streptococcus uberis, environmental organisms commonly found in organic matter (Riekerink et al., 2006).

If somatic cells are able to move from the bloodstream to the udder quickly, intramammary infections can be eliminated, and SCC will quickly return to normal levels (Sordillo et al., 1997). High ambient temperatures inhibited the quick movement of somatic cells to the mammary gland when reacting to a chemotactic challenge (Elvinger et al., 1992). Tao et al. (2018) explained that a compromised immune system could be partially responsible for the increase in SCC and mastitis incidence during summer months.

Incidence of lameness has been shown to increase with an increase in ambient temperature. This could be due to the increase in standing time in attempt to increase body surface area when cows are experiencing heat stress (Provolo and Riva, 2009; Sanders et al., 2009). In addition, thin soles, white line disease, ulcers, and sole punctures all contribute to lameness and therefore can increase the likelihood for early culling from the herd (Sanders et al., 2009; Das et al., 2016). 
Incidence of metritis may increase during periods of heat stress. Heat stress during late gestation may suppress uterine defense mechanisms, or high ambient temperature and high humidity may contribute to an increased pathogen load in the environment that may induce disease (Santos and Ribiero, 2014). Cows that develop uterine diseases, such as metritis, have reduced fertilization, compromised early embryonic development, and increased risk of pregnancy loss (Santos and Ribiero, 2014).

Subacute ruminal acidosis has become an increasing problem in well-managed, high-yielding dairy herds: $19 \%$ of cows housed in confinement experience subacute ruminal acidosis in early lactation, and $26 \%$ in midlactation. In grazing cattle, the prevalence of subacute ruminal acidosis was determined to be between 10 and $15 \%$ for early- and mid-lactation cows (O'Grady et al., 2008). Heat stress affects feeding behavior of dairy cattle by causing reduced DMI and increased intake of high-energy feed and minimal intake of forage; therefore, cows experiencing heat stress could be predisposed to ruminal acidosis (Collier et al., 2006).

\section{Behavior}

Animal health professionals and dairy producers use changes in behavioral patterns of cows as a tool for identifying poor health and welfare (Mattachini et al., 2013). Measures of lying behavior are an important indicator of cow comfort and provide valuable information on how cows interact with their environment (Tucker et al., 2004; O'Driscoll et al., 2008). The duration and number of lying bouts are used as indicators to assess the welfare of cattle (Fregonesi and Leaver, 2002). On average, a typical dairy cow spends 11 to 14 $\mathrm{h} / \mathrm{d}$ lying down in thermoneutral conditions (Wechsler et al., 2000; Cook et al., 2005; Ito et al., 2010). As ambient temperature increases, dairy cows will reduce lying time by $30 \%$ to increase body surface area for heat dissipation (Cook et al., 2007; Schütz et al., 2011). Increased standing time can increase energy expenditure and alter nutrient use, which, in turn, can increase maintenance requirements (West, 2003).

Cows under an increased heat load may change their behavior to improve cooling (Polsky and von Keyserlingk, 2017). In hot conditions, cows will spend more time standing and decrease activity, to increase surface area for heat abatement, sensible water loss, radiating surface area, and air movement via convection (Cook et al., 2007; Allen et al., 2015; Polsky and von Keyserlingk, 2017). Increased standing time in a 24 -h period caused by heat stress may contribute to decreased milk production, increased disease prevalence (Cook et al.,
2007; Polsky and von Keyserlingk, 2017), and increased body temperature (Anderson et al., 2013). Blood flow to the udder is limited in a standing position compared with a lying position, contributing to the decrease in milk production (Rulquin and Caudal, 1992). When blood flow to the udder is limited, the amount of nutrient uptake by the mammary gland is reduced (Delamaire and Guinard-Flament, 2006).

Body temperature increases as a response to heat stress (Armstrong, 1994). Some researchers have reported that an increase in core body temperature may be positively correlated with the amount of time cows spend standing in a 24-h period (Cook et al., 2007; Anderson et al., 2013). Allen et al. (2015) stated that the difference in core body temperature related to the probability that a cow is standing or lying is very small $\left(0.07^{\circ} \mathrm{C}\right)$, regardless of the level of heat stress being experienced. This difference may not be physiologically relevant but could potentially explain the behavioral change of whether a heat-stressed cow finds it necessary to stand or lie down. The same study found that cows were more likely to be lying during the hottest part of the day $(1600 \mathrm{~h})$, when body temperature average is the greatest, than during the cooler nighttime hours.

Uninterrupted lying time plays an important role in the health of cattle. With increased lying time, the occurrence of hoof diseases and lameness may decrease and can contribute to increased DMI and rumination (Grant, 2006; Kominkova et al., 2015; Horký et al., 2017). Some researchers have reported that extended periods of standing can act as a major risk factor for lameness (Cook and Nordlund, 2004; Allen et al., 2015). With increased standing time, the pressure inside the claw capsule is increased, leading to restricted oxygen supply and restricted blood flow and, therefore, increased lameness (Grandin, 2016). Whether that association is caused by increased time spent standing (Cook et al., 2007) or altered nutrient metabolism due to the decrease in DMI that occurs (Cook et al., 2004) is unknown. Future research should consider the effect of increased standing time during periods of heat stress on lameness in both confinement and grazing settings.

Adult cattle rarely engage in sleep while standing, meaning that decreased lying time can have an effect on welfare. Lack of sleep due to increased time spent standing, especially lack of rapid eye movement sleep, can alter the endocrine system, increase energy expenditure, and weaken the immune system (Grandin, 2016).

When provided shade, heat-stressed cows demonstrate more time spent ruminating (Blackshaw and Blackshaw, 1994), higher milk yield (West, 2003), and decreased body temperatures compared with unshaded 
heat-stressed cows (Kendall et al., 2006). To thermoregulate, dairy cows will spend most of their time seeking and standing in shaded areas in pasture (Schütz et al., 2008; Vizzotto et al., 2015). Cows will continue seeking shade and standing in an attempt to reduce the internal body temperature, even when deprived of lying for $12 \mathrm{~h}$ (Schütz et al., 2008). When experiencing heat stress, cattle will actively seek shade during the heat of the day, and if no shade is available, an animal will continue to stand, to attempt to dissipate the accumulating heat (Bianca, 1968; Finch, 1986).

Cooling with sprinklers can lower respiration rate (RR) in hot conditions (Valtorta and Gallardo, 2004; Kendall et al., 2007; Chen et al., 2013). The provision of sprinklers as heat abatement may also reduce irritation from insects on cattle (Kendall et al., 2007). In a New Zealand study by Kendall et al. (2007), 4 different heat abatement strategies (control or no heat abatement, shade, shade and sprinklers, and sprinklers) were applied to cows in the holding pen for $90 \mathrm{~min}$ before milking, and insect-avoidance behaviors were observed (number of tail flicks and foot stomps). Half as many tail flicks and foot stomps were observed in the treatment groups with sprinklers compared with the control and shade groups. Results from Eicher et al. (2001) are in agreement that both of these behaviors were positively associated with insect avoidance and fly numbers.

\section{Indicators of Heat Stress}

Body temperature is a summary of all thermoregulatory events, making it an important indicator of health, reproductive success, and productivity in livestock animals (St-Pierre et al., 2003; Brown-Brandl et al., 2005; Duff and Galyean, 2007). An increase in body temperature can be associated with illness, injury, heat stress, toxin exposure, or other health-related issues (Koltes et al., 2018). Production losses in domestic animals are largely attributed to increases in maintenance requirements associated with sustaining constant body temperature, and to altered feed intake (Mader et al., 2002; Davis et al., 2003; Mader and Davis, 2004).

Cattle exhibit seasonal variations in body temperature reflective of ambient temperature (Fordham et al., 1988). Measuring body temperature continuously throughout the day can be advantageous due to the fluctuations in environmental temperature in a $24-\mathrm{h}$ period. Some researchers have found that body temperature in cattle may follow a distinct circadian rhythm with a range of 0.2 to $0.9^{\circ} \mathrm{C}$ (Nakamura et al., 1983; Lefcourt et al., 1999; Al-Haidary et al., 2001; Piccione and Refinetti, 2003), with the minimum body temperature in the morning and the maximum in the late afternoon (Kendall and Webster, 2009). In summer months, the mean body temperature and the amplitude of body temperature rhythm are higher than in the spring or winter months (Berman and Morag, 1971). Factors influencing body temperature include overall health, environment, ambient temperature, activity level, estrus, pregnancy status, breed, eating and drinking behaviors, and excitement (Lefcourt et al., 1999). Multiple researchers have stated that body temperature lags ambient temperature by 1 to $5 \mathrm{~h}$ and is dependent on ambient conditions, meaning that using body temperature as an indicator of heat stress could result in a delayed producer response (Scott et al., 1983; Hahn, 1989; Hahn, 1999; Mader et al., 2002; Brown-Brandl et al., 2005).

Technologies may be used for measuring body temperature from different regions of the body, including rectal, tympanic, reticulorumen, vaginal, and skin. Each region used for body temperature measurement has advantages and disadvantages. Reticulorumen temperature can be automated for routine, continuous monitoring; however, water intake, especially large volumes of water and cold water, can cause a dip in reticulorumen temperature. Due to the proximity to the hypothalamic thermosensitive site, tympanic temperature is considered a reliable method of body temperature and has a reduced lag time compared with rectal temperature (Seawright et al., 1983; Bergen and Kennedy, 2000). Davis et al. (2003) found that when using sprinklers in a feedlot in periods of heat stress, tympanic temperature may be significantly reduced.

Measurement of body temperature with rectal thermometers is commonly used to identify illness in cattle (Vickers et al., 2010). Collecting rectal temperature data is time-consuming and requires a person to manually record the temperature, meaning that collecting many time points in a $24-\mathrm{h}$ period is unrealistic. However, vaginal temperature may be associated with rectal temperature and can provide the ability to capture diurnal changes in body temperature (Vickers et al., 2010). By attaching a data logger to a controlled internal drug release insert and inserting the device into the vaginal cavity, body temperature can be collected throughout the entire 24-h period. Thermal images can be taken to assess skin temperature in cattle. Salles et al. (2016) found that thermal images taken from the forehead of the cow are most closely related to rectal temperatures in Jersey cattle, whereas the left and right flanks were most closely related to the calculated THI.

Providing shade for cattle on pasture can have beneficial effects on body temperature, but its effectiveness may vary depending on cow breed, environmental con- 
ditions, and the amount of black or white in the coat of the cow (Roman-Ponce et al., 1977, 1981; Ingraham et al., 1979; Hansen, 1990; Muller et al., 1994; Davison et al., 1996; Fisher et al., 2008). In a South African study, when maximum temperature was $\leq 25^{\circ} \mathrm{C}$, the researchers found no effects of shade on body temperature (Muller et al., 1994). However, multiple researchers have found that when ambient temperature exceeds $25^{\circ} \mathrm{C}$, non-shaded cows have an increased body temperature compared with cows with access to shade (Roman-Ponce et al., 1977; Valtorta et al., 1997; Fisher et al., 2008).

Respiration rates of cattle can be influenced by multiple factors, including age, level of production, body condition, DMI, housing design, cooling systems, and previous exposure to hot conditions (Gaughan et al., 2000). Gaughan et al. (2000) reported that under hot conditions, a cycle of ambient temperature ranging from 24 to $39^{\circ} \mathrm{C}$, the increase in $\mathrm{RR}$ varied from 2.8 breaths/min to 3.3 breaths/min for each $1^{\circ} \mathrm{C}$ increase in ambient temperature. As body condition of the cows increased, $\mathrm{RR}$ was higher by 1 breath $/ \mathrm{min}$ for each $1^{\circ} \mathrm{C}$ increase in ambient temperature, compared with thinner cows. These researchers stated that even when cows had previously experienced hot conditions, cattle with higher BCS were less heat tolerant. Animals are able to adapt to hot environmental conditions through gradual acclimation (Prosser and Brown, 1969). However, when hot conditions are prolonged, as in the summer months in the southeastern United States, cows are less likely to acclimate, further accentuating the negative effects of heat stress (Kadzere et al., 2002).

Increase in $\mathrm{RR}$ is one of the most sensitive phenotypic indicators of heat stress; $\mathrm{RR}>60$ breaths/min is an indicator of heat stress in lactating dairy cows (Shultz, 1984; Berman et al., 1985). When RR is $\geq 120$ breaths/ min, the cow is experiencing severe stress (Hahn, 1999). Respiration rate increases with ambient temperature but lags solar radiation by approximately $1 \mathrm{~h}$ (BrownBrandl et al., 2005). Some researchers mention that RR may have a ceiling, or maximum RR, ranging from under 100 breaths/min to approximately 200 breaths/ min (Kibler and Brody, 1949, 1950; Worstell and Brody, 1953; Hales and Findlay, 1968; Spiers et al., 1994; Gaughen et al., 2000). In contrast, other researchers have not noted an RR ceiling (Spain and Spiers, 1996; Hahn, 1999; Brown-Brandl et al., 2005). Berman et al. (1985) reported that $\mathrm{RR}$ began to increase above 50 to 60 breaths/min when ambient temperature reached $25^{\circ} \mathrm{C}$. In another study, researchers found that Jersey cows had much higher RR compared with Holstein cows. They added that this could be attributed to Jersey cows' ability to dissipate heat more efficiently than Holstein cows (Kibler and Brody, 1950).
Researchers have found a breed effect in relation to heat tolerance (Seath and Miller, 1948; Kadzere et al., 2002; Keister et al., 2002; Bryant et al., 2007; Smith et al., 2013). Smith et al. (2013) stated that Holstein cows dropped in milk production during both moderate $(79 \leq \mathrm{THI}<90)$ and severe $(90 \leq \mathrm{THI})$ heat stress, whereas Jersey cows dropped in milk production only in severe heat stress. Milk fat percentage for Holstein cows dropped in moderate and severe heat stress, compared with mild heat stress. For Jersey cows, milk fat percentage did not decrease at any level of heat stress experienced. The researchers concluded that Jersey cows appeared to be more heat tolerant than Holstein cows; however, Holstein cows still produced a larger volume of milk, due to their genetic advantage over Jerseys for total milk yield.

Breed and parity can have an effect on body temperature (Kendall and Webster, 2009; Stone et al., 2017). In a New Zealand study, no significant differences in vaginal temperature were observed for Holstein, Jersey, or Holstein $\times$ Jersey crossbred cows. However, the authors noted a tendency for Jersey cows to maintain a higher vaginal temperature in the summer months compared with Holstein and Holstein $\times$ Jersey crossbred cows (Kendall and Webster, 2009). Stone et al. (2017) reports that primiparous Holstein cows had a higher reticulorumen temperature $\left(39.3 \pm 0.2^{\circ} \mathrm{C}\right)$ compared with Jersey cows $\left(38.9 \pm 0.2^{\circ} \mathrm{C}\right)$, and crossbred cows had a higher reticulorumen temperature compared with Jersey cows $\left(39.2 \pm 0.2^{\circ} \mathrm{C}\right)$. However, significant differences in reticulorumen temperatures in multiparous cows were not exhibited. Jersey cows may have an advantage over Holstein cows or crossbred cows, due to their ability to maintain a lower reticulorumen temperature under heat stress conditions (Liang et al., 2013; Smith et al., 2013).

The amount of dark- or light-colored hair can affect how tolerant of heat an animal may be. Brown-Brandl et al. (2006) compared the heat tolerance of feedlot heifers of different breeds. The study included 2 breeds with dark-colored coats (Angus, all black; and MARC III, mostly dark red) and 2 breeds with light-colored coats (Gelbvieh, tan; and Charolais, mostly white or off-white). The researchers found that the 2 breeds with dark-colored coats had a significantly higher RR (96.6 and 95.6 breaths/min for Angus and MARC III, respectively) compared with the 2 light-colored breeds (88.7 and 80.7 breaths/min for Gelbvieh and Charolais, respectively). They saw this same effect with panting scores and skin surface temperatures. The use of thermal imaging may be beneficial for exploring how heat tolerant animals of differing colors may be.

Various management practices have been implemented to improve the welfare of heat-stressed cows (Polsky 
and von Keyserlingk, 2017). When cattle on pasture have access to shade, RR can decrease compared with cattle without shade (Brown-Brandl et al., 2005). In a study with shaded and non-shaded feedlot cattle, Brown-Brandl et al. (2005) reported that regardless of weather, the RR of shaded and non-shaded cattle were similar until $1100 \mathrm{~h}$. At $1100 \mathrm{~h}$, RR of shaded cattle became steady, whereas the RR of non-shaded cattle continued to rise. The importance of providing shade during hot conditions has been well documented (Blackshaw and Blackshaw, 1994; Mitlöehner et al., 2002; Brown-Brandl et al., 2003).

Two important mechanisms of evaporative heat loss for cattle are panting and sweating, where sweating can account for up to $80 \%$ of total evaporative heat loss (Robertshaw, 1985). Panting occurs when sensible heat is used to heat the water vapor and remove the built-up heat in the form of vaporized moisture from the lungs. Sweating occurs when moisture is evaporated from the skin surface (Gebremedhin et al., 2008). With high ambient temperature and relative humidity, evaporative heat loss via panting and sweating becomes less effective (Sparke et al., 2001). In addition, sweating and panting contribute further to metabolic heat production, thereby increasing the heat load (Bianca, 1968). Gebremedhin et al. (2008) found that Jersey cows sweat less than black or white Holstein cows. The researchers stated that these results support the theory that Jersey cows are more heat tolerant than Holstein cows.

Cattle experiencing heat stress may exhibit openmouthed, labored panting (Sparke et al., 2001). Some researchers have used a panting scoring system as a tool for measuring heat stress (Gaughan et al., 2000; Mader et al., 2006). Tresoldi et al. (2018) observed panting characteristics and RR of heat-stressed dry lot cattle and found that RR was higher when cows were exhibiting any panting characteristic (drooling, open mouth, protruding tongue) compared with when they were not showing any of these signs.

\section{CONCLUSIONS}

Managing heat stress in the southeast United States is a challenge. This region experiences high ambient temperatures and humidity for 4 to 6 mo every year, causing a major strain on lactating dairy cows. Effects on performance include reduced milk yield, reduced fertility, and decreased milk quality, which all lead to an increased profit loss for dairy producers. Physically modifying the environment cows live in with shade, misters, fans, or sprinklers, or a combination of these heat abatement methods, could help alleviate the negative effects associated with heat stress.

\section{ACKNOWLEDGMENTS}

The authors have not stated any conflicts of interest.

\section{REFERENCES}

Abeni, F., M. G. Maianti, L. Calamari, V. Cappa, and L. Stefanini. 1993. Effects of heat stress on lactating dairy cows and feeding strategy to reduce its impact on milk yield and quality. Annali della Facolta di Agraria Universita Milano. 33:151-170.

Al-Haidary, A., D. E. Spiers, G. E. Rottinghaus, G. B. Garner, and M. R. Ellersieck. 2001. Thermoregulatory ability of beef heifers following intake of endophyte-infected tall fescue during controlled heat challenge. J. Anim. Sci. 79:1780-1788. https://doi.org/10.2527/ 2001.7971780x.

Albright, J., and C. Alliston. 1971. Effects of varying the environment upon the performance of dairy cattle. J. Anim. Sci. 32:566-577. https://doi.org/10.2527/jas1971.323566x.

Allen, J. D., L. W. Hall, R. J. Collier, and J. F. Smith. 2015. Effect of core body temperature, time of day, and climate conditions on behavioral patterns of lactating dairy cows experiencing mild to moderate heat stress. J. Dairy Sci. 98:118-127. https://doi.org/10 .3168/jds.2013-7704.

Anderson, S. D., B. J. Bradford, J. P. Harner, C. B. Tucker, C. Y. Choi, J. D. Allen, L. W. Hall, S. Rungruang, R. J. Collier, and J. F. Smith. 2013. Effects of adjustable and stationary fans with misters on core body temperature and lying behavior of lactating dairy cows in a semiarid climate. J. Dairy Sci. 96:4738-4750. https: //doi.org/10.3168/jds.2012-6401.

Ando, S., M. C. Mundia, Y. Nakamura, and S. Yamamoto. 1997. Effect of feed intake levels on heart rate, heat production, and mean body temperature of Holstein heifers. Anim. Sci. Technol. 68:177-184.

Archer, S. C., F. Mc Coy, W. Wapenaar, and M. J. Green. 2013. Association of season and herd size with somatic cell count for cows in Irish, English, and Welsh dairy herds. Vet. J. 196:515-521. https:/ /doi.org/10.1016/j.tvjl.2012.12.004.

Arieli, A., G. Adin, and I. Bruckental. 2004. The effect of protein intake on performance of cows in hot environmental temperatures. J. Dairy Sci. 87:620-629. https://doi.org/10.3168/jds.S0022 -0302(04)73204-X.

Armstrong, D. V. 1994. Heat stress interaction with shade and cooling. J. Dairy Sci. 77:2044-2050. https://doi.org/10.3168/jds.S0022 $-0302(94) 77149-6$.

Atrian, P., and H. A. Shahryar. 2012. Heat stress in dairy cows (A review). J. Zool. (Lond.) 2:31-37.

Badinga, L., R. J. Collier, W. W. Thatcher, and C. J. Wilcox. 1985. Effects of climatic and management factors on conception rate of dairy cattle in subtropical environment. J. Dairy Sci. 68:78-85. https://doi.org/10.3168/jds.S0022-0302(85)80800-6.

Basiricò, L., U. Bernabucci, P. Morera, N. Lacetera, and A. Nardone. 2009. Gene expression and protein secretion of apolipoprotein $\mathrm{B}_{100}$ $\left(\mathrm{ApoB}_{100}\right)$ in transition dairy cows under hot or thermoneutral environments. Ital. J. Anim. Sci. 8(suppl. 2):492-594. https://doi .org/10.4081/ijas.2009.s2.592.

Bauman, D. E., C. J. Peel, W. D. Steinhour, P. J. Reynolds, H. F. Tyrrell, C. Brown, and G. L. Harland. 1988. Effect of bovine somatotropin on metabolism of lactating dairy cows: Influence on rates of irreversible loss and oxidation of glucose and nonesterified fatty acids. J. Nutr. 118:1031-1040.

Bauman, D. E., J. W. Perfield II, K. Harvatine, and L. H. Baumgard. 2008. Regulation of fat synthesis by conjugated linoleic acid: Lactation and the ruminant model. J. Nutr. 138:403-409. https://doi .org/10.1093/jn/138.2.403.

Baumgard, L. H., and R. P. Rhoads Jr.. 2013. Effects of heat stress on postabsorptive metabolism and energetics. Annu. Rev. Anim. Biosci. 1:311-337. https://doi.org/10.1146/annurev-animal-031412 -103644 .

Beede, D. K., and R. J. Collier. 1986. Potential nutritional strategies for intensively managed cattle during thermal stress. J. Dairy Sci. 62:543-554. https://doi.org/10.2527/jas1986.622543x. 
Bergen, R. D., and A. D. Kennedy. 2000. Relationship between vaginal and tympanic membrane temperature in beef heifers. Can. J. Anim. Sci. 80:515-518. https://doi.org/10.4141/A00-033.

Berman, A., Y. Folman, M. Kaim, M. Mamen, Z. Herz, D. Wolfenson, A. Arieli, and Y. Graber. 1985. Upper critical temperatures and forced ventilation effects for high-yielding dairy cows in a subtropical climate. J. Dairy Sci. 68:1488-1495. https://doi.org/10.3168/ jds.S0022-0302(85)80987-5.

Berman, A., and M. Morag. 1971. Nycterohemeral patterns of thermoregulation in high-yielding dairy cows in a hot dry near-natural climate. Aust. J. Agric. Res. 22:671. https://doi.org/10.1071/ AR9710671.

Berman, A. 2005. Estimates of heat stress relief needs for Holstein dairy cows. J. Anim. Sci. 83:1377-1384. https://doi.org/10.2527/ 2005.8361377x.

Bernabucci, U., L. Basiricò, P. Morera, D. Dipasquale, A. Vitali, F. Piccioli Cappelli, and L. Calamari. 2015. Effect of summer season on milk protein fractions in Holstein cows. J. Dairy Sci. 98:18151827. https://doi.org/10.3168/jds.2014-8788.

Bernabucci, U., S. Biffani, L. Buggiotti, A. Vitali, N. Lacetera, and A. Nardone. 2014. The effects of heat stress in Italian Holstein dairy cattle. J. Dairy Sci. 97:471-486. https://doi.org/10.3168/jds.2013 -6611 .

Bertocchi, L., A. Vitali, N. Lacetera, A. Nardone, G. Varisco, and U. Bernabucci. 2014. Seasonal variations in the composition of Holstein cow's milk and temperature-humidity index relationship. Animal 8:667-674. https://doi.org/10.1017/S1751731114000032.

Bianca, W. 1968. Thermoregulation. Pages 97-118 in Adaptation of Domestic Animals. E. S. E. Hafez, ed. Lea and Febiger, Philadelphia, PA.

Biggers, B. G., R. D. Geisert, R. P. Wetteman, and D. S. Buchanan. 1987. Effect of heat stress on early embryonic development in the beef cow. J. Anim. Sci. 64:1512-1518. https://doi.org/10.2527/ jas1987.6451512x

Blackshaw, J. K., and A. W. Blackshaw. 1994. Heat stress in cattle and the effect of shade on production and behaviour: A review. Aust. J. Exp. Agric. 34:285-295. https://doi.org/10.1071/EA9940285.

Bouraoui, R., M. Lahmar, A. Majdoub, M. Djemali, and R. Belyea. 2002. The relationship of temperature-humidity index with milk production of dairy cows in a Mediterranean climate. Anim. Res. 51:479-491. https://doi.org/10.1051/animres:2002036.

Braganza, K., D. J. Karoly, and J. M. Arblaster. 2004. Diurnal temperature range as an index of global climate change during the twentieth century. Geophys. Res. Lett. 31:L13217. https://doi.org/ 10.1029/2004GL019998.

Brenu, E. W., D. R. Staines, L. Tajouri, T. Huth, K. J. Ashton, and S. M. Marshall-Gradisnik. 2013. Heat shock proteins and regulatory T cells. Autoimmune Dis. 2013:813256. https://doi.org/10.1155/ $2013 / 813256$.

Brown-Brandl, T. M., R. A. Eigenberg, and J. A. Nienaber. 2006. Heat stress risk factors of feedlot heifers. Livest. Sci. 105:57-68. https:/ /doi.org/10.1016/j.livsci.2006.04.025.

Brown-Brandl, T. M., R. E. Eigenberg, J. A. Nienaber, and G. L. Hahn. 2005. Dynamic response indicators of heat stress in shaded and non-shaded feedlot cattle: Part 1. Analyses of indicators. Biosyst. Eng. 90:451-462. https://doi.org/10.1016/j.biosystemseng .2004.12.006.

Brown-Brandl, T. M., J. A. Nienaber, R. A. Eigenberg, G. L. Hahn, and H. Freetly. 2003. Thermoregulatory responses of feeder cattle. J. Therm. Biol. 28:149-157. https://doi.org/10.1016/S0306 -4565(02)00052-9.

Bryant, J. R., N. Lopez-Villalobos, J. E. Pryce, C. W. Holmes, D. L. Johnson, and D. J. Garrick. 2007. Environmental sensitivity in New Zealand dairy cattle. J. Dairy Sci. 90:1538-1547. https://doi .org/10.3168/jds.S0022-0302(07)71639-9.

Cardot, V., Y. Le Roux, and S. Jurjanz. 2008. Drinking behavior of lactating dairy cows and prediction of their water intake. J. Dairy Sci. 91:2257-2264. https://doi.org/10.3168/jds.2007-0204.

Cavestany, D., A. B. El-Wishy, and R. H. Foote. 1985. Effect of season and high environmental temperature on fertility of Holstein cattle.
J. Dairy Sci. 68:1471-1478. https://doi.org/10.3168/jds.S0022 -0302(85)80985-1.

Chen, J. M., K. E. Schütz, and C. B. Tucker. 2013. Dairy cows use and prefer feed bunks fitted with sprinklers. J. Dairy Sci. 96:50355045. https://doi.org/10.3168/jds.2012-6282.

Collier, R. J., D. K. Beede, W. W. Thatcher, L. A. Israel, and C. J. Wilcox. 1982. Influences of environment and its modification on dairy animal health and production. J. Dairy Sci. 65:2213-2227. https://doi.org/10.3168/jds.S0022-0302(82)82484-3.

Collier, R. J., G. E. Dahl, and M. J. Vanbaale. 2006. Major advances associated with environmental effects on dairy cattle. J. Dairy Sci. 89:1244-1253. https://doi.org/10.3168/jds.S0022-0302(06)72193 $-2$.

Collier, R. J., R. M. Eley, A. K. Sharma, R. J. Pereira, and D. E. Buffington. 1981. Shade management in subtropical environment for milk yield and composition in Holstein and Jersey cows. J. Dairy Sci. 64:844-849. https://doi.org/10.3168/jds.S0022-0302(81)82656 -2 .

Collier, R. J., R. B. Zimbelman, R. P. Rhoads, M. L. Rhoads, and L. H. Baumgard. 2012. A re-evaluation of temperature humidity index (THI) and black globe humidity index (BGHI) on milk production in high producing dairy cows. Western Dairy Management Conference. Reno, NV

Cook, N. B., T. B. Bennett, and K. V. Nordlund. 2005. Monitoring indices of cow comfort in free-stall-housed dairy herds. J. Dairy Sci. 88:3876-3885. https://doi.org/10.3168/jds.S0022-0302(05)73073 $-3$.

Cook, N. B., R. L. Mentink, T. B. Bennett, and K. Burgi. 2007. The effect of heat stress and lameness on time budgets of lactating dairy cows. J. Dairy Sci. 90:1674-1682. https://doi.org/10.3168/ jds.2006-634.

Cook, N. B., and K. Nordlund. 2004. An update on dairy cow freestall design, Preconvention Seminar 7, Dairy herd problem investigation strategies. American Association of Bovine Practitioners 37th Annual Convention, Fort Worth, TX, Sept. 20-22, 2004.

Cook, N. B., K. V. Nordlund, and G. R. Oetzel. 2004. Environmental influences on claw horn lesions associated with laminitis and subacute ruminal acidosis in dairy cows. J. Dairy Sci. 87(E. Suppl.):E36-E46.

Coppock, C. E. 1978. Feeding energy to dairy cattle. Pages 265-268 in Large Dairy Management. C. E. Coppock, ed. University Presses of Florida, Gainesville, FL.

Cowley, F. C., D. G. Barber, A. V. Houlihan, and D. P. Poppi. 2015. Immediate and residual effects of heat stress and restricted intake on milk protein and casein composition and energy metabolism. J. Dairy Sci. 98:2356-2368. https://doi.org/10.3168/jds.2014-8442.

da Silva, R. G., N. La Scala Jr., and H. Tonhati. 2003. Radiative properties of the skin and haircoat of cattle and other animals. Trans. ASAE 46:913-918. https://doi.org/10.13031/2013.13567.

Das, R., L. Sailo, N. Verma, P. Bharti, J. Saikia, Imtiwati, and R. Kumar. 2016. Impact of heat stress on health and performance of dairy animals: A review. Vet. World 9:260-268. https://doi.org/10 .14202/vetworld.2016.260-268.

Dash, S., A. Chakravarty, A. Singh, A. Upadhyay, M. Singh, and S. Yousuf. 2016. Effect of heat stress on reproductive performances of dairy cattle and buffaloes: A review. Vet. World 9:235-244. https: //doi.org/10.14202/vetworld.2016.235-244.

Davis, M. S., T. L. Mader, S. M. Holt, and A. M. Parkhurst. 2003. Strategies to reduce feedlot cattle heat stress: Effects on tympanic temperature. J. Anim. Sci. 81:649-661. https://doi.org/10.2527/ 2003.813649x.

Davison, T., M. McGowan, D. Mayer, B. Young, N. Jonsson, A. Hall, A. Matschoss, P. Goodwin, J. Goughan, and M. Lake. 1996. Managing Hot Cows in Australia. Queensland Department of Primary Industries, Brisbane, Australia.

de Haas, Y., H. W. Barkema, and R. F. Veerkamp. 2002. The effect of pathogen-specific clinical mastitis on the lactation curve for somatic cell count. J. Dairy Sci. 85:1314-1323.

De Rensis, F., I. Garcia-Ispierto, and F. López-Gatius. 2015. Seasonal heat stress: Clinical implications and hormone treatments for the 
fertility of dairy cows. Theriogenology 84:659-666. https://doi .org/10.1016/j.theriogenology.2015.04.021.

De Rensis, F., P. Marconi, T. Capelli, F. Gatti, F. Facciolongo, S. Franzini, and R. J. Scaramuzzi. 2002. Fertility in postpartum dairy cows in winter or summer following estrus synchronization and fixed time AI after the induction of an LH surge with GnRH or hCG. Theriogenology 58:1675-1687. https://doi.org/10.1016/ S0093-691X(02)01075-0.

De Rensis, F., and R. J. Scaramuzzi. 2003. Heat stress and seasonal effects on reproduction in the dairy cow - A review. Theriogenology 60:1139-1151. https://doi.org/10.1016/S0093-691X(03)00126-2.

Delamaire, E., and J. Guinard-Flament. 2006. Increasing milking intervals decreases the mammary blood flow and mammary uptake of nutrients in dairy cows. J. Dairy Sci. 89: 3439-3446.

De Vries, A., and C. A. Risco. 2005. Trends and seasonality of reproductive performance in Florida and Georgia dairy herds from 1976 to 2002. J. Dairy Sci. 88:3155-3165.

Dhakal, C. K., P. P. Regmi, I. P. Dhakal, B. Khanal, U. K. Bhatta, S. R. Barsila, and B. Acharya. 2013. Perception, impact, and adaptation to climate change: An analysis of livestock system in Nepal. J. Anim. Sci. Adv. 3:462-471.

Dikmen, S., E. Alava, E. Pontes, J. M. Fear, B. Y. Dikmen, T. A. Olson, and P. J. Hansen. 2008. Differences in thermoregulatory ability between slick-haired and wild-type lactating Holstein cows in response to acute heat stress. J. Dairy Sci. 91:3395-3402.

do Amaral, B. C., E. E. Connor, S. Tao, M. J. Hayen, J. W. Bubolz, and G. E. Dahl. 2011. Heat stress abatement during the dry period influences metabolic gene expression and improves immune status in the transition period of dairy cows. J. Dairy Sci. 94:86-96. https://doi.org/10.3168/jds.2009-3004.

Dosogne, H., E. Meyer, A. Sturk, J. van Loon, A. M. Massart-Leën, and C. Burvenich. 2002. Effect of enrofloxacin treatment on plasma endotoxin during bovine Escherichia coli mastitis. Inflamm. Res. 51:201-205. https://doi.org/10.1007/PL00000293.

Drackley, J. K. 1999. Biology of dairy cows during the transition period: The final frontier? J. Dairy Sci. 82:2259-2273.

Dransfield, M. B. G., R. L. Nebel, R. E. Pearson, and L. D. Warnick. 1998. Timing of insemination for dairy cows identified in estrus by a radiotelemetric estrus detection system. J. Dairy Sci. 81:18741882. https://doi.org/10.3168/jds.S0022-0302(98)75758-3.

Duff, G. C., and M. L. Galyean. 2007. Board-invited review: Recent advances in management of highly stressed, newly received feedlot cattle. J. Anim. Sci. 85:823-840. https://doi.org/10.2527/jas.2006 -501 .

Edwards, J. L., and P. J. Hansen. 1997. Differential responses of bovine oocytes and preimplantation embryos to heat shock. Mol. Reprod. Dev. 46:138-145.

Eicher, S. D., J. L. Morrow-Tesch, J. L. Albright, and R. E. Williams. 2001. Tail-docking alters fly numbers, fly-avoidance behaviors, and cleanliness, but not physiological measures. J. Dairy Sci. 84:18221828. https://doi.org/10.3168/jds.S0022-0302(01)74621-8.

El-Tarabany, M. S., and K. M. El-Bayoumi. 2015. Reproductive performance of backcross Holstein $\times$ Brown Swiss and their Holstein contemporaries under subtropical environmental conditions. Theriogenology 83:444-448. https://doi.org/10.1016/j.theriogenology 2014.10.010

Elvinger, F., R. P. Natzke, and P. J. Hansen. 1992. Interactions of heat stress and bovine somatotropin affecting physiology and immunology of lactating cows. J. Dairy Sci. 75:449-462. https://doi.org/10 .3168/jds.S0022-0302(92)77781-9.

Ferreira, F., and A. De Vries. 2015. Effects of season and herd milk volume on somatic cell counts of Florida dairy farms. J. Dairy Sci. 98:4182-4197.

Finch, V. A. 1986. Body temperature in beef cattle: Its control and relevance to production in the tropics. J. Anim. Sci. 62:531-542. https://doi.org/10.2527/jas1986.622531x.

Finch, V. A., and D. Western. 1977. Cattle colors in pastoral herds: Natural selection or social preference? Ecology 58:1384-1392. https://doi.org/10.2307/1935090.
Fisher, A. D., N. Roberts, S. J. Bluett, G. A. Verkerk, and L. R. Matthews. 2008. Effects of shade provision on the behaviour, body temperature and milk production of grazing dairy cows during a New Zealand summer. N. Z. J. Agric. Res. 51:99-105. https://doi .org/10.1080/00288230809510439.

Flanagan, S. W., P. L. Moseley, and G. R. Buettner. 1998. Increased flux of free radicals in cells subjected to hyperthermia: Detection by electron paramagnetic resonance spin trapping. FEBS Lett. 431:285-286. https://doi.org/10.1016/S0014-5793(98)00779-0.

Folk, G. E. 1974. Temperature regulation. Pages 87-132 in Textbook of Environmental Physiology. G. E. Folk, ed. Lea and Febiger, Philadelphia, PA.

Fordham, D. P., P. Rowlinson, and T. T. McCarthy. 1988. Oestrus detection in dairy cows by milk temperature measurement. Res. Vet. Sci. 44:366-374. https://doi.org/10.1016/S0034-5288(18)30873-7.

Fournel, S., V. Ouellet, and È. Charbonneau. 2017. Practices for alleviating heat stress of dairy cows in humid continental climates: A literature review. Animals (Basel) 7:37. https://doi.org/10.3390/ ani7050037.

Fregonesi, J. A., and J. D. Leaver. 2002. Influence of space allowance and milk yield level on behaviour, performance and health of dairy cows housed in straw-yard and cubicle systems. Livest. Prod. Sci 78:245-257. https://doi.org/10.1016/S0301-6226(02)00097-0.

Fuquay, J. W. 1981. Heat stress as it affects production. J. Anim. Sci. 52:164-174. https://doi.org/10.2527/jas1981.521164x.

Gangwar, P. C., C. C. Branton, and D. L. Evans. 1965. Reproductive and physiological responses of Holstein heifers to controlled and natural climatic conditions. J. Dairy Sci. 48:222-227. https://doi .org/10.3168/jds.S0022-0302(65)88200-5.

Gao, S. T., J. Guo, S. Y. Quan, X. M. Nan, M. V. Sanz Fernandez, L. H. Baumgard, and D. P. Bu. 2017. The effects of heat stress on protein metabolism in lactating Holstein cows. J. Dairy Sci. 100:5040-5049. https://doi.org/10.3168/jds.2016-11913.

García-Ispierto, I., F. López-Gatius, G. Bech-Sabat, P. Santolaria, J. Yániz, C. Nogareda, F. De Rensis, and M. López-Béjar. 2007. Climate factors affecting conception rate of high producing dairy cows in northeastern Spain. Theriogenology 67:1379-1385. https:/ /doi.org/10.1016/j.theriogenology.2007.02.009.

Gaughan, J. B., S. M. Holt, G. L. Hahn, T. L. Mader, and R. Eigenberg. 2000. Respiration rate- Is it a good measure of heat stress in cattle? Asian-Australas. J. Anim. Sci. 13(Suppl. C):329-332.

Gebremedhin, K. G. 1985. Heat exchange between livestock and the environment. Pages 15-33 in Stress Physiology in Livestock, Vol. 1. M. K. Yosef, ed. CRC Press, Boca Raton, FL.

Gebremedhin, K. G., P. E. Hillman, C. N. Lee, R. J. Collier, S. T. Willard, J. D. Arthington, and T. M. Brown-Brandl. 2008. 2008 American Society of Agricultural and Biological Engineers Annual Meeting. 51:2167-2178.

Giesecke, W. H. 1985. The effect of stress on udder health of dairy cows. Onderstepoort J. Vet. Res. 52:175-193.

Godden, S., P. Rapnicki, S. Stewart, J. Fetrow, A. Johnson, R. Bey, and R. Farnsworth. 2003. Effectiveness of an internal teat seal in the prevention of new intramammary infections during the dry and early-lactation periods in dairy cows when used with a dry cow intramammary antibiotic. J. Dairy Sci. 86:3899-3911. https://doi .org/10.3168/jds.S0022-0302(03)73998-8.

Grandin, T. 2016. Evaluation of the welfare of cattle housed in outdoor feedlot pens. Vet. Anim. Sci. 1-2:23-28. https://doi.org/10 $.1016 /$ j.vas.2016.11.001.

Grant, R. J. 2006. Dairy cow behaviour and management. Int. Dairy Topics 5:21-25.

Gwazdauskas, F. C., C. J. Wilcox, and W. W. Thatcher. 1975. Environmental and management factors affecting conception rate in a subtropical climate. J. Dairy Sci. 58:88-92. https://doi.org/10 .3168/jds.S0022-0302(75)84523-1.

Hahn, G. L. 1989. Body temperature rhythms in farm animals-A review and reassessment relative to environmental influences. In Proc. 11th International Society of Biomechanics Congress, the Hague, the Netherlands. 11:325-337. 
Hahn, G. L. 1999. Dynamic responses of cattle to thermal heat loads. J. Anim. Sci. 77(Suppl. 2):10-20. https://doi.org/10.2527/1997 .77suppl_210x.

Hahn, G. L., and D. D. Osburn. 1969. Feasibility of summer environmental control for dairy cattle based on expected production losses. Trans. ASAE 12:448-451. https://doi.org/10.13031/2013 .38862 .

Hales, J. R. S., and J. D. Findlay. 1968. Respiration of the ox: Normal values and the effects of exposure to hot environments. Respir. Physiol. 4:333-352. https://doi.org/10.1016/0034-5687(68)90039 $-\mathrm{X}$.

Hammami, H., J. Bormann, N. M'hamdi, H. H. Montaldo, and N. Gengler. 2013. Evaluation of heat stress effects on production traits and somatic cell score of Holsteins in a temperate environment. J. Dairy Sci. 96:1844-1855. https://doi.org/10.3168/jds.2012-5947.

Hammami, H., J. Vandenplas, M.-L. Vanrobays, B. Rekik, C. Bastin, and N. Gengler. 2015. Genetic analysis of heat stress effects on yield traits, udder health, and fatty acids of Walloon Holstein cows. J. Dairy Sci. 98:4956-4968. https://doi.org/10.3168/jds.2014 $-9148$.

Hansen, P. J. 1990. Effects of coat colour on physiological responses to solar radiation in Holsteins. Vet. Rec. 127:333-334.

Hansen, P. J. 2013. Antecedents of mammalian fertility: Lessons from the heat-stressed cow regarding the importance of oocyte competence for fertilization and embryonic development. Anim. Front. 3:34-39. https://doi.org/10.2527/af.2013-0031.

Hansen, P. J., and C. Aréchiga. 1999. Strategies for managing reproduction in the heat-stressed dairy cow. J. Anim. Sci. 77(Suppl. 2):36. https://doi.org/10.2527/1997.77suppl_236x.

Harmon, R. J. 1994. Physiology of mastitis and factors affecting somatic cell counts1. J. Dairy Sci. 77:2103-2112. https://doi.org/10 .3168/jds.S0022-0302(94)77153-8.

Hill, D. L., and E. Wall. 2015. Dairy cattle in a temperate climate: The effects of weather on milk yield and composition depend on management. Animal 9:138-149. https://doi.org/10.1017/ S1751731114002456.

Hoffman, M. P., and H. L. Self. 1972. Factors affecting water consumption by feedlot cattle. J. Anim. Sci. 35:871-876. https://doi.org/10 $.2527 /$ jas1972.354871x

Holter, J. B., and W. E. Urban Jr.. 1992. Water partitioning and intake prediction in dry and lactating Holstein cows. J. Dairy Sci. 75:1472-1479. https://doi.org/10.3168/jds.S0022-0302(92)77904 -1 .

Honig, H., L. Ofer, M. Kaim, S. Jacobi, D. Shinder, and E. Gershon. 2016. The effect of cooling management on blood flow to the dominant follicle and estrous cycle length at heat stress. Theriogenology 86:626-634. https://doi.org/10.1016/j.theriogenology.2016.02.017.

Horký, P., J. Skladanka, P. Nevrkla, D. Falta, I. Caslavova, and P. Knot. 2017. Effect of protein concentrate supplementation on the composition of amino acids in milk from dairy cows in an organic farming system. Potr. 11:88-95. https://doi.org/10.5219/707.

Houpt, T. R. 1984. Water balance and excretion. In Duke's Physiology of Domestic Animals. 10th ed. M. J. Swenson, ed. Comstock Publishing Co., Ithaca, NY.

Howell, J. L., J. W. Fuquay, and A. E. Smith. 1994. Corpus luteum growth and function in lactating Holstein cows during spring and summer. J. Dairy Sci. 77:735-739. https://doi.org/10.3168/jds .S0022-0302(94)77007-7.

Huber, J. T., G. Higginbotham, R. A. Gomez-Alarcon, R. B. Taylor, K. H. Chen, S. C. Chan, and Z. Wu. 1994. Heat stress interactions with protein, supplemental fat, and fungal cultures. J. Dairy Sci. 77:2080-2090. https://doi.org/10.3168/jds.S0022-0302(94)77151 $-4$.

Igono, M. O., H. D. Johnson, B. J. Steevens, G. F. Krause, and M. D. Shanklin. 1987. Physiological, productive, and economic benefits of shade, spray, and fan system versus shade for Holstein cows during summer heat. J. Dairy Sci. 70:1069-1079. https://doi.org/ 10.3168/jds.S0022-0302(87)80113-3.

Ingraham, R. H., D. D. Gillette, and W. D. Wagner. 1974. Relationship of temperature and humidity to conception rate of Holstein cows in subtropical climate. J. Dairy Sci. 57:476-481. https://doi .org/10.3168/jds.S0022-0302(74)84917-9.

Ingraham, R. H., R. W. Stanley, and W. C. Wagner. 1979. Seasonal effects of tropical climate on shaded and non-shaded cows as measured by rectal temperature, adrenal cortex hormones, thyroid hormone, and milk production. Am. J. Vet. Res. 40:1792-1797.

IPCC (Intergovernmental Panel on Climate Change). 2018. Climate Change: Special report; Summary for Policymakers. Accessed May 6, 2019. https://www.ipcc.ch/site/assets/uploads/sites/2/2019/ 05/SR15_SPM_version_report_LR.pdf.

Ito, K., M. A. G. von Keyserlingk, S. J. LeBlanc, and D. M. Weary. 2010. Lying behavior as an indicator of lameness in dairy cows. J. Dairy Sci. 93:3553-3560. https://doi.org/10.3168/jds.2009-2951.

Jingar, S. C., R. K. Mehla, and M. Singh. 2014. Climatic effects on occurrence of clinical mastitis in different breeds of cows and buffaloes. Arch. Zootec. 63:473-482. https://doi.org/10.4321/S0004 $-05922014000300008$

Johnson, H. D. 1987. Bioclimate and livestock. Pages 3-16 in Bioclimatology and the Adaptation of Livestock. H. D. Johnson, ed. Elsevier Science Publisher, Amsterdam, the Netherlands.

Johnson, H. D., and R. G. Yeck. 1964. Age and temperature effects on TDN, water consumption and balance of dairy calves and heifers exposed to environmental temperatures of 35 to $95^{\circ} \mathrm{F}$. Environmental physiology with special reference to domestic animals. LXVIII. Missouri Agric. Exp. Sm. Res. Bull. 865.

Kadzere, C., M. Murphy, N. Silanikove, and E. Maltz. 2002. Heat stress in lactating dairy cows: A review. Livest. Prod. Sci. 77:5991. https://doi.org/10.1016/S0301-6226(01)00330-X.

Keister, Z. O., K. D. Moss, H. M. Zhang, T. Teegerstrom, R. A Edling, R. J. Collier, and R. L. Ax. 2002. Physiological responses in thermal stressed Jersey cows subjected to different management strategies. J. Dairy Sci. 85:3217-3224. https://doi.org/10.3168/jds .S0022-0302(02)74410-X.

Kendall, P. E., G. A. Verkerk, J. R. Webster, and C. B. Tucker. 2007. Sprinklers and shade cool cows and reduce insect-avoidance behavior in pasture-based dairy systems. J. Dairy Sci. 90:3671-3680. https://doi.org/10.3168/jds.2006-766.

Kendall, P. E., P. P. Nielsen, J. R. Webster, G. A. Verkerk, R. P. Littlejohn, and L. R. Matthews. 2006. The effects of providing shade to lactating dairy cows in a temperate climate. Livest. Sci. 103:148-157. https://doi.org/10.1016/j.livsci.2006.02.004.

Kendall, P. E., and J. R. Webster. 2009. Season and physiological status affects the circadian body temperature rhythm of dairy cows. Livest. Sci. 125:155-160. https://doi.org/10.1016/j.livsci.2009.04 .004 .

Key, N., S. Sneeringer, and D. Marquardt. 2014. Climate change, heat stress, and U.S. dairy production. USDA-Economic Research Report \#175.

Kibler, H. H., and S. Brody. 1949. Influence of temperature, $50^{\circ} \mathrm{F}$ to $5^{\circ} \mathrm{F}$ and $50^{\circ} \mathrm{F}$ to $95^{\circ} \mathrm{F}$, on heat production and cardiorespiratory activities of dairy cattle. Environmental Physiology and Shelter Engineering Series VII, Research Bulletin 450, Missouri Agricultural Experiment Station, University of Missouri, Columbia, MO.

Kibler, H. H., and S. Brody. 1950. Effects of temperature, $50^{\circ} \mathrm{F}$ to $105^{\circ} \mathrm{F}$ and $50^{\circ} \mathrm{F}$ to $9^{\circ} \mathrm{F}$ on heat production and cardiorespiratory activities in Brahman, Jersey and Holstein cows. Environmental Physiology and Shelter Engineering Series XI, Research Bulletin 464, Missouri Agricultural Experiment Station, University of Missouri, Columbia, MO.

Knapp, D. M., and R. R. Grummer. 1991. Response of lactating dairy cows to fat supplementation during heat stress. J. Dairy Sci. 74:2573-2579. https://doi.org/10.3168/jds.S0022-0302(91)78435 -X.

Koltes, J. E., D. A. Koltes, B. E. Mote, J. Tucker, and D. S. Hubbell III.. 2018. Automated collection of heat stress data in livestock: New technologies and opportunities. Transl. Anim. Sci. 2:319-323. https://doi.org/10.1093/tas/txy061.

Kominkova, M., P. Horký, N. Cernei, K. Tmejova, B. Ruttkay-Nedecky, R. Guran, M. Pohanka, O. Zitka, V. Adam, and R. Kizek. 2015. Optimization of the glutathione detection by high performance 
liquid chromatography with electrochemical detection in the brain and liver of rats fed with taurine. Int. J. Electrochem. Sci. 10:1716-1727.

Kumar, S., A. Kumar, and M. Kataria. 2011. Effect of heat stress in tropical livestock and different strategies for its amelioration. J. Stress Physiol. Biochem. 7:45-54.

Lacetera, N., U. Bernabucci, B. Ronchi, and A. Nardone. 2003. Physiological and productive consequences of heat stress: The case of dairy ruminants. Pages 45-59 in Interactions Between Climate and Animal Production. Wageningen Academic Publishers, Wageningen, the Netherlands.

Lee, J. I., and I. H. Kim. 2007. Pregnancy loss in dairy cows: The contributing factors, the effects on reproductive performance and the economic impact. J. Vet. Sci. 8:283-288. https://doi.org/10 .4142 /jvs.2007.8.3.283.

Lefcourt, A. M., J. B. Huntington, R. M. Akers, D. L. Wood, and J. Bitman. 1999. Circadian and ultradian rhythms of body temperature and peripheral concentrations of insulin and nitrogen in lactating dairy cows. Domest. Anim. Endocrinol. 16:41-55. https: //doi.org/10.1016/S0739-7240(98)00047-2.

Li, L., Y. Sun, J. Wu, X. Li, M. Luo, and G. Wang. 2015. The global effect of heat on gene expression in cultured bovine mammary epithelial cells. Cell Stress Chaperones 20:381-389. https://doi.org/ 10.1007/s12192-014-0559-7.

Liang, D., C. L. Wood, K. J. McQuerry, D. L. Ray, J. D. Clark, and J. M. Bewley. 2013. Influence of breed, milk production, season, and ambient temperature on dairy cow reticulorumen temperature. J. Dairy Sci. 96:5072-5081. https://doi.org/10.3168/jds.2012-6537.

Lievaart, J. J., H. W. Barkema, W. D. J. Kremer, J. van den Broek, J. H. M. Verheijden, and J. A. P. Heesterbeek. 2007. Effect of herd characteristics, management practices, and season on different categories of the herd somatic cell count. J. Dairy Sci. 90:4137-4144.

Little, W., K. A. Collis, P. T. Gleed, B. F. Sansom, W. M. Allen, and A. J. Quick. 1980. Effect of reduced water intake by lactating dairy cows on behavior, milk yield and blood composition. Vet. Rec. 106:547-551. https://doi.org/10.1136/vr.106.26.547.

Lough, D. S., D. K. Beede, and C. J. Wilcox. 1990. Effects of feed intake and thermal stress on mammary blood flow and other physiological measurements in lactating dairy cows. J. Dairy Sci. 73:325-332. https://doi.org/10.3168/jds.S0022-0302(90)78677-8.

Mader, T. L., and M. S. Davis. 2004. Effect of management strategies on reducing heat stress of feedlot cattle: Feed and water intake. J. Anim. Sci. 82:3077-3087. https://doi.org/10.2527/2004 $.82103077 \mathrm{x}$.

Mader, T. L., M. S. Davis, and T. Brown-Brandl. 2006. Environmental factors influencing heat stress in feedlot cattle. J. Anim. Sci. 84:712-719. https://doi.org/10.2527/2006.843712x.

Mader, T. L., S. M. Holt, G. L. Hahn, M. S. Davis, and D. E. Spiers. 2002. Feeding strategies for managing heat load in feedlot cattle. J. Anim. Sci. 80:2373-2382. https://doi.org/10.2527/2002.8092373x.

Maia, A. S. C., R. G. da Silva, and E. C. A. Bertipaglia. 2005. Environmental and genetic variation of the effective radiative properties of the coat of Holstein cows under tropical conditions. Livest. Prod. Sci. 92:307-315. https://doi.org/10.1016/j.livprodsci.2004 .09.004.

Mattachini, G., E. Riva, C. Bisaglia, J. C. A. M. Pompe, and G. Provolo. 2013. Methodology for quantifying the behavioral activity of dairy cows in freestall barns. J. Anim. Sci. 91:4899-4907. https:// doi.org/10.2527/jas.2012-5554.

Maust, L. E., R. E. McDowell, and N. W. Hooven. 1972. Effect of summer weather on performance of Holstein cows in three stages of lactation. J. Dairy Sci. 55:1133-1139. https://doi.org/10.3168/ jds.S0022-0302(72)85635-2.

McDowell, R. E. 1972. Improvement of Livestock Production in Warm Climates. W. H. Freeman and Co., San Francisco, CA.

Mitlöehner, F. M., M. L. Galyean, and J. J. McClone. 2002. Shade effects on performance, carcass traits, physiology, and behavior of heat-stress feedlot heifers. J. Anim. Sci. 80:2043-2050.

Moody, E. G., P. J. Van Soest, R. E. McDowell, and G. L. Ford. 1967. Effect of high temperature and dietary fat on performance of lac- tating cows. J. Dairy Sci. 50:1909-1916. https://doi.org/10.3168/ jds.S0022-0302(67)87747-6.

Moore, C. E., J. K. Kay, M. J. VanBaale, and L. H. Baumgard. 2005. Calculating and improving energy balance during times of nutrient limitation. Pages 173-185 in Proc. Southwest Nutr. Conf.

Morse, D., M. DeLorenzo, C. Wilcox, R. Collier, R. Natzke, and D. Bray. 1988. Climatic effects on occurrence of clinical mastitis. J. Dairy Sci. 71:848-853. https://doi.org/10.3168/jds.S0022 -0302(88)79626-5.

Morton, J. M., W. P. Tranter, D. G. Mayer, and N. N. Jonsson. 2007. Effects of environmental heat on conception rates in lactating dairy cows: Critical periods of exposure. J. Dairy Sci. 90:22712278. https://doi.org/10.3168/jds.2006-574.

Muller, C. J. C., J. A. Botha, W. A. Coetzer, and W. A. Smith. 1994. Effect of shade on various parameters of Friesian cows in a Mediterranean climate in South Africa. 2. Physiological responses. S. Afr. J. Anim. Sci. 24:56-60.

Muñoz, G., F. Rondelli, L. Maiztegui, S. Gherardi, F. Tolini, J. Amelong, G. Fernández, and A. Coronel. 2014. Effects of heat waves on lactating Argentinian Holstein cows in the Dairy Module. Cienc. Vet. (Heredia) 16:113-127.

Murphy, M. R. 1992. Symposium: Nutritional factors affecting animal water and waste quality: Water metabolism of dairy cattle. J. Dairy Sci. 75:326-333. https://doi.org/10.3168/jds.S0022 -0302(92)77768-6.

Nakamura, R. M., C. T. Araki, N. L. Clarke, and L. W. G. Kam. 1983. Temperature telemetry studies in dairy cattle in hot climates. Pages 464-469 in National Conference on Agricultural Electronics Applications. American Society of Agricultural Engineers, Chicago, IL

Nardone, A., N. Lacetera, U. Bernabucci, and B. Ronchi. 1997. Composition of colostrum from dairy heifers exposed to high air temperatures during late pregnancy and the early postpartum period. J. Dairy Sci. 80:838-844. https://doi.org/10.3168/jds.S0022 $-0302(97) 76005-3$.

Nasr, M. A., and M. S. El-Tarabany. 2017. Impact of three THI levels on somatic cell count, milk yield and composition of multiparous Holstein cows in a subtropical region. J. Therm. Biol. 64:73-77. https://doi.org/10.1016/j.jtherbio.2017.01.004.

National Research Council (NRC). 2001. Nutrient Requirements of Dairy Cattle. 7th rev. ed. National Academy Press, Washington, DC.

Norman, H. D., F. L. Guinan, L. M. Walton, and J. Dürr. 2019. Somatic cell counts of milk from Dairy Herd Improvement herds during 2019. Council on Dairy Cattle Breeding, Beltsville, MD.

O'Driscoll, K., L. Boyle, and A. Hanlon. 2008. A brief note on the validation of a system for recording lying behaviour in dairy cows. Appl. Anim. Behav. Sci. 111:195-200. https://doi.org/10.1016/j .applanim.2007.05.014.

O'Grady, L., M. L. Doherty, and F. J. Mulligan. 2008. Subacute ruminal acidosis (SARA) in grazing Irish dairy cows. Vet. J. 176:44-49. https://doi.org/10.1016/j.tvjl.2007.12.017.

Olde Riekerink, R. G., H. W. Barkema, and H. Stryhn. 2007. The effect of season on somatic cell count and the incidence of clinical mastitis. J. Dairy Sci. 90:1704-1715. https://doi.org/10.3168/jds .2006-567.

Olson, T. A., C. Lucena, C. C. Chase Jr., and A. C. Hammond. 2003. Evidence of a major gene influencing hair length and heat tolerance in Bos taurus cattle. J. Anim. Sci. 81:80-90. https://doi.org/ 10.2527/2003.81180x.

Ominski, K. H., A. D. Kennedy, K. M. Wittenberg, and S. A. Moshtaghi Nia. 2002. Physiological and production responses to feeding schedule in lactating dairy cows exposed to short-term, moderate heat stress. J. Dairy Sci. 85:730-737. https://doi.org/10 .3168/jds.S0022-0302(02)74130-1.

Orihuela, A. 2000. Some factors affecting the behavioral manifestation of oestrus in cattle: A review. Appl. Anim. Behav. Sci. 70:1-16. https://doi.org/10.1016/S0168-1591(00)00139-8.

Pahlavani, M. A., and M. D. Harris. 1998. Effect of in vitro generation of oxygen free radicals on $\mathrm{T}$ cell function in young and old rats. 
Free Radic. Biol. Med. 25:903-913. https://doi.org/10.1016/S0891 $-5849(98) 00124-5$.

Perano, K. M., J. G. Usack, L. T. Angenent, and K. G. Gebremedhin. 2015. Production and physiological responses of heat-stressed lactating dairy cattle to conductive cooling. J. Dairy Sci. 98:52525261. https://doi.org/10.3168/jds.2014-8784.

Pereira, M. H. C., C. P. Sanches, T. G. Guida, A. D. P. Rodrigues, F. L. Aragon, M. B. Veras, P. T. Borges, M. C. Wiltbank, and J. L. M. Vasconcelos. 2013. Timing of prostaglandin $\mathrm{F}_{2 \alpha}$ treatment in an estrogen-based protocol for timed artificial insemination or timed embryo transfer in lactating dairy cows. J. Dairy Sci. 96:28372846. https://doi.org/10.3168/jds.2012-5840.

Piccione, G., and R. Refinetti. 2003. Thermal chronobiology of domestic animals. Front. Biosci. 8:S258-S264. https://doi.org/10.2741/ 1040.

Polsky, L., and M. A. von Keyserlingk. 2017. Invited review: Effects of heat stress on dairy cattle welfare. J. Dairy Sci. 100:8645-8657. https://doi.org/10.3168/jds.2017-12651.

Prosser, C. L., and F. A. Brown. 1969. Comparative Animal Physiology. Saunders Co., London, UK.

Provolo, G., and E. Riva. 2009. One year study of lying and standing behaviour of dairy cows in a freestall barn in Italy. J. Agric. Eng. $2: 27-33$.

Purwanto, B. P., Y. Abo, R. Sakamoto, F. Furumoto, and S. Yamamoto. 1990. Diurnal patterns of heat production and heart rate under thermoneutral conditions in Holstein Friesian cows differing in milk production. J. Agric. Sci. 114:139-142. https://doi.org/10 $.1017 /$ S0021859600072117.

Qu, M., J. Wan, and X. Hao. 2014. Analysis of diurnal air temperature range change in the continental United States. Weather Clim. Extrem. 4:86-95. https://doi.org/10.1016/j.wace.2014.05.002.

Raghubeer, E. V., and I. R. Matches. 1990. Temperature range for growth of Escherichia coli serotype 0157:H7 and selected coliforms in E. coli medium. J. Clin. Microbiol. 28:803-805. https://doi.org/ 10.1128/JCM.28.4.803-805.1990.

Ratnakaran, A. P., V. Sejian, V. Sanjo Jose, S. Vaswani, M. Bagath, G. Krishnan, V. Beena, P. Indira Devi, G. Varma, and R. Bhatta. 2017. Behavioral responses to livestock adaptation to heat stress challenges. Asian J. Anim. Sci. 11:1-13.

Ravagnolo, O., I. Misztal, and G. Hoogenboom. 2000. Genetic component of heat stress in dairy cattle, development of heat index function. J. Dairy Sci. 83:2120-2125. https://doi.org/10.3168/jds .S0022-0302(00)75094-6.

Ray, D. E. 1991. Heat stress in feedlot cattle. Pages 69-81 in Proc. Southwest Nutr. and Mgmt. Conf., Tempe, AZ.

Regan, W. M., and G. A. Richardson. 1938. Reactions of the dairy cow to changes in environmental temperature. J. Dairy Sci. 21:73-79. https://doi.org/10.3168/jds.S0022-0302(38)95617-6.

Rejeb, M., T. Najar, and M. B. M'Rad. 2012. The effect of heat stress on dairy cow's performance and animal behaviour. Int. J. Plant Anim. Environ. Sci. 2:29-34.

Rhoads, M. L., R. P. Rhoads, M. J. VanBaale, R. J. Collier, S. R. Sanders, W. J. Weber, B. A. Crooker, and L. H. Baumgard. 2009. Effects of heat stress and plane of nutrition on lactating Holstein cows: I. Production, metabolism and aspects of circulating somatotropin. J. Dairy Sci. 92:1986-1997. https://doi.org/10.3168/ jds.2008-1641.

Richards, J. I. 1985. Effect of high daytime temperatures on the intake and utilisation of 212 water in lactating Friesian cows. Trop. Anim. Health Prod. 17:209-217. https://doi.org/10.1007/BF02356978.

Riekerink, R. O., H. Barkema, D. F. Kelton, G. P. Keefe, and D. T. Scholl. 2006. Risk factors for herd-level infection of contagious mastitis pathogens on Canadian dairy farms. Pages 598 in Proceedings of the 11th International Symposium on Veterinary Epidemiology and Economics, Cairns, Australia.

Robertshaw, D. 1985. Heat loss of cattle. Pages 55-66 in Stress Physiology in Livestock. M. K. Yousef ed. CRC Press, Boca Raton, FL.

Roman-Ponce, H., W. W. Thatcher, D. E. Buffington, C. J. Wilcox, and H. H. Van Horn. 1977. Physiological and production responses of dairy cattle to a shade structure in a subtropical environ- ment. J. Dairy Sci. 60:424-430. https://doi.org/10.3168/jds.S0022 -0302(77)83882-4.

Roman-Ponce, H., W. W. Thatcher, and C. J. Wilcox. 1981. Hormonal interrelationships and physiological responses of lactating dairy cows to a shade management system in a subtropical environment. Theriogenology 16:139-154. https://doi.org/10.1016/0093 $-691 \mathrm{X}(81) 90097-2$.

Rulquin, H., and J.P. Caudal. 1992. Effects of lying or standing on mammary blood flow and heart rate of dairy cows. Annales de zootechnie, INRA/EDP Sciences 41:101.

Russell, J. B., and H. J. Strobel. 1989. Effect of ionophores on ruminal fermentation. Appl. Environ. Microbiol. 55:1-6. https://doi.org/10 .1128/AEM.55.1.1-6.1989.

Salles, M. S., S. C. da Silva, F. A. Salles, L. C. Roma Jr., L. El Faro, P. A. Bustos MacLean, C. E. Lins de Oliveira, and L. S. Martello. 2016. Mapping the body surface temperature of cattle by infrared thermography. J. Therm. Biol. 62:63-69.

Sanders, A. H., J. K. Shearer, and A. De Vries. 2009. Seasonal incidence of lameness and risk factors associated with thin soles, white line disease, ulcers, and sole punctures in dairy cattle. J. Dairy Sci. 92:3165-3174

Santos, J. E. P., and E. S. Ribeiro. 2014. Impact of animal health on reproduction of dairy cows. Anim. Reprod. 11:254-269.

Sargeant, J. M., Y. H. Schukken, and K. E. Leslie. 1998. Ontario bulk milk somatic cell count reduction program: Progress and outlook. J. Dairy Sci. 81:1545-1554. https://doi.org/10.3168/jds.S0022 -0302(98)75720-0.

Schukken, Y. H., A. Weersink, K. E. Leslie, and S. W. Martin. 1993. Dynamics and regulation of bulk milk somatic cell counts. Can. J. Vet. Res. 57:131.

Schüller, L. K., O. Burfeind, and W. Heuwieser. 2014. Impact of heat stress on conception rate of dairy cows in the moderate climate considering different temperature-humidity index thresholds, periods relative to breeding, and heat load indices. Theriogenology 81:1050-1057. https://doi.org/10.1016/j.theriogenology.2014.01 .029 .

Schütz, K. E., A. R. Rogers, N. R. Cox, J. R. Webster, and C. B. Tucker. 2011. Dairy cattle prefer shade over sprinklers: Effects on behavior and physiology. J. Dairy Sci. 94:273-283. https://doi .org $/ 10.3168 / \mathrm{jds} .2010-3608$.

Schütz, K. E., N. R. Cox, and L. R. Matthews. 2008. How important is shade to dairy cattle? Choice between shade or lying following different levels of lying deprivation. Appl. Anim. Behav. Sci. 114:307-318. https://doi.org/10.1016/j.applanim.2008.04.001.

Scott, I. M., H. D. Johnson, and G. L. Hahn. 1983. Effect of programmed diurnal temperature cycles on plasma thyroxine level, body temperature, and feed intake of Holstein dairy cows. Int. J. Biometeorol. 27:47-62. https://doi.org/10.1007/BF02186300.

Seath, D. M., and G. D. Miller. 1948. Effect of water sprinkling with and without air movement on cooling dairy cows. J. Dairy Sci. 31:361-366. https://doi.org/10.3168/jds.S0022-0302(48)92217-6.

Seawright, G. L., R. R. Brown, K. Campbell, R. L. Levings, and C. T. Araki. 1983. Comparison of remotely acquired deep-body and subdermal temperature measurements for detecting fever in cattle. Pages 517-528 in National Conference on Agricultural Electronics Applications. American Society of Agricultural Engineers, Chicago, IL.

Settivari, R. S., J. N. Spain, M. R. Ellersieck, J. C. Byatt, R. J. Collier, and D. E. Spiers. 2007. Relationship of thermal status to productivity in heat-stressed dairy cows given recombinant bovine somatotropin. J. Dairy Sci. 90:1265-1280. https://doi.org/10.3168/ jds.S0022-0302(07)71615-6.

Sharma, A. K., L. A. Rodriguez, G. Mekonnen, C. J. Wilcox, K. C. Bachman, and R. J. Collier. 1983. Climatological and genetic effects on milk composition and yield. J. Dairy Sci. 66:119-126.

Shock, D. A., S. J. LeBlanc, K. E. Leslie, K. Hand, M. A. Godkin, J. B. Coe, and D. F. Kelton. 2015. Exploring the characteristics and dynamics of Ontario dairy herds experiencing increases in bulk milk somatic cell count during the summer. J. Dairy Sci. 98:37413753. https://doi.org/10.3168/jds.2014-8675. 
Shultz, T. A. 1984. Weather and shade effects on cow corral activities. J. Dairy Sci. 67:868-873. https://doi.org/10.3168/jds.S0022 -0302(84)81379-X.

Shwartz, G., M. L. Rhoads, M. J. VanBaale, R. P. Rhoads, and L. H. Baumgard. 2009. Effects of a supplemental yeast culture on heatstressed lactating Holstein cows. J. Dairy Sci. 92:935-942. https:/ /doi.org/10.3168/jds.2008-1496.

Silper, B. F., A. M. L. Madureira, M. Kaur, T. A. Burnett, and R. L. A. Cerri. 2015. Short communication: Comparison of estrus characteristics in Holstein heifers by 2 activity monitoring systems. J. Dairy Sci. 98:3158-3165. https://doi.org/10.3168/jds.2014-9185.

Silva, R. G., D. A. E. F. Morais, and M. M. Guilhermino. 2007. Evaluation of thermal stress indexes for dairy cows in tropical regions. Rev. Bras. Zootec. 36:1192-1198. https://doi.org/10.1590/S1516 -35982007000500028 .

Smith, D. L., T. Smith, B. Rude, and S. Ward. 2013. Comparison of the effects of heat stress on milk and component yields and somatic cell score in Holstein and Jersey cows. J. Dairy Sci. 96:3028-3033. https://doi.org/10.3168/jds.2012-5737.

Smith, K. L., D. A. Todhunter, and P. S. Schoenberger. 1985. Environmental mastitis: Cause, prevalence, prevention. In Symposium: Environmental effect on cow health and performance. J. Dairy Sci. 68:1531-1553. https://doi.org/10.3168/jds.S0022-0302(85)80993 -0 .

Sordillo, L. M., K. Shafer-Weaver, and D. DeRosa. 1997. Immunobiology of the mammary gland. J. Dairy Sci. 80:1851-1865. https:// doi.org/10.3168/jds.S0022-0302(97)76121-6.

Spain, J. N., and D. E. Spiers. 1996. Effects of supplemental shade on thermoregulatory response of calves to heat challenge in a hutch environment. J. Dairy Sci. 79:639-646. https://doi.org/10.3168/ jds.S0022-0302(96)76409-3.

Sparke, E. J., B. A. Young, J. B. Gaughan, S. M. Holt, and P. J. Goodwin. 2001. Heat Load in Feedlot Cattle. On Farm. Meat and Livestock Australia, Sydney, Australia.

Spiers, D. E., J. N. Spain, J. D. Sampson, and R. P. Rhoads. 2004. Use of physiological parameters to predict milk yield and feed intake in heat-stressed dairy cows. J. Therm. Biol. 29:759-764. https://doi .org/10.1016/j.jtherbio.2004.08.051.

Spiers, D. E., D. W. Vogt, H. D. Johnson, G. B. Garner, and C. N. Murphy. 1994. Heat-stress responses of temperate and tropical breeds of Bos taurus cattle. Arch. Latinoam. Prod. Anim. 2:41-52.

St-Pierre, N. R., B. Cobanov, and G. Schnitkey. 2003. Economic losses from heat stress by US livestock industries. J. Dairy Sci. 86(Suppl.):E52-E77.

Steele, M. 2016. Does heat stress affect immune function in dairy cows? Veterinary Evidence 1.

Steiger Burgos, M., M. Senn, F. Sutter, M. Kreuzer, and W. Langhans. 2001. Effect of water restriction on feeding and metabolism in dairy cows. Am. J. Physiol. Regul. Integr. Comp. Physiol. 280:R418R427. https://doi.org/10.1152/ajpregu.2001.280.2.R418.

Stone, A. E., B. W. Jones, C. A. Becker, and J. M. Bewley. 2017. Influence of breed, milk yield, and temperature-humidity index on dairy cow lying time, neck activity, reticulorumen temperature, and rumination behavior. J. Dairy Sci. 100:2395-2403. https://doi .org/10.3168/jds.2016-11607.

Stull, C. L., L. L. McV. Messam, C. A. Collar, N. G. Peterson, A. R. Castillo, B. A. Reed, K. L. Andersen, and W. R. VerBoort. 2008. Precipitation and temperature effects on mortality and lactation parameters of dairy cattle in California. J. Dairy Sci. 91:45794591. https://doi.org/10.3168/jds.2008-1215.

Summer, A., I. Lora, P. Formaggioni, and F. Gottardo. 2018. Impact of heat stress on milk and meat production. Anim. Front. 9:39-46. https://doi.org/10.1093/af/vfy026.

Sunagawa, K., I. Nagamine, Y. Kamata, N. Niino, Y. Taniyama, K. Kinjo, and A. Matayoshi. 2015. Nighttime cooling is an effective method for improving milk production in lactating goats exposed to hot and humid environment. Asian-Australas. J. Anim. Sci. 28:966-975. https://doi.org/10.5713/ajas.14.0890.

Tao, S., R. Orellana, X. Weng, T. Marins, G. Dahl, and J. Bernard. 2018. Symposium review: The influences of heat stress on bovine mammary gland function. J. Dairy Sci. 101:5642-5654.
Tresoldi, G., K. E. Schütz, and C. B. Tucker. 2018. Cooling cows with sprinklers: Timing strategy affects physiological responses to heat load. J. Dairy Sci. 101:11237-11246. https://doi.org/10.3168/jds .2018-14917.

Tucker, C. B., D. M. Weary, and D. Fraser. 2004. Free-stall dimensions: Effects on preference and stall usage. J. Dairy Sci. 87:12081216. https://doi.org/10.3168/jds.S0022-0302(04)73271-3.

USDA. 2018. Milk: Production per Cow by Year, US. Accessed Apr. 15, 2019. https://www.nass.usda.gov/Charts_and_Maps/Milk _Production_and_Milk_Cows/cowrates.php.

Valtorta, S. E., and M. R. Gallardo. 2004. Evaporative cooling for Holstein dairy cows under grazing conditions. Int. J. Biometeorol. 48:213-217. https://doi.org/10.1007/s00484-003-0196-9.

Valtorta, S. E., P. E. Leva, and M. L. Gallardo. 1997. Evaluation of different shades to improve dairy cattle well-being in Argentina. Int J. Biometeorol. 41:65-67. https://doi.org/10.1007/s004840050055.

Veissier, I., M. M. Mialon, and K. H. Sloth. 2017. Short communication: Early modification of the circadian organization of cow activity in relation to disease or estrus. J. Dairy Sci. 100:3969-3974. https://doi.org/10.3168/jds.2016-11853.

Vickers, L. A., O. Burfeind, M. A. G. Von Keyserlingk, D. M. Veira, D. M. Weary, and W. Heuwieser. 2010. Technical note: Comparison of rectal and vaginal temperatures in lactating dairy cows. J. Dairy Sci. 93:5246-5251. https://doi.org/10.3168/jds.2010-3388.

Vitali, A., M. Segnalini, L. Bertocchi, U. Bernabucci, A. Nardone and N. Lacetera. 2009. Seasonal pattern of mortality and relationships between mortality and temperature-humidity index in dairy cows. J. Dairy Sci. 92:3781-3790. https://doi.org/10.3168/jds.2009 $-2127$.

Vizzotto, E. F., V. Fischer, A. Thaler Neto, A. S. Abreu, M. T. Stumpf, D. Werncke, F. A. Schmidt, and C. M. McManus. 2015. Access to shade changes behavioral and physiological attributes of dairy cows during the hot season in the subtropics. Animal 9:1559-1566. https://doi.org/10.1017/S1751731115000877.

Waage, S., S. Sviland, and S. A. Odegaard. 1998. Identification of risk factors for clinical mastitis in dairy heifers. J. Dairy Sci. 81:12751284. https://doi.org/10.3168/jds.S0022-0302(98)75689-9.

Wechsler, B., J. Schaub, K. Friedli, and R. Hauser. 2000. Behaviour and leg injuries in dairy cows kept in cubicle systems with straw bedding or soft lying mats. Appl. Anim. Behav. Sci. 69:189-197. https://doi.org/10.1016/S0168-1591(00)00134-9.

West, J. W. 2003. Effects of heat-stress on production in dairy cattle. J. Dairy Sci. 86:2131-2144. https://doi.org/10.3168/jds.S0022 -0302(03)73803-X.

West, J. W., G. M. Hill, J. M. Fernandez, P. Mandebvu, and B. G. Mullinix. 1999. Effects of dietary fiber on intake, milk yield, and digestion by lactating dairy cows during cool or hot, humid weather. J. Dairy Sci. 82:2455-2465. https://doi.org/10.3168/jds.S0022 -0302(99)75497-4.

West, J. W., B. G. Mullinix, and J. K. Bernard. 2003. Effects of hot, humid weather on milk temperature, dry matter intake, and milk yield of lactating dairy cows. J. Dairy Sci. 86:232-242. https://doi .org/10.3168/jds.S0022-0302(03)73602-9.

Wheelock, J. B., R. P. Rhoads, M. J. VanBaale, S. R. Sanders, and L. H. Baumgard. 2010. Effects of heat stress on energetic metabolism in lactating Holstein cows. J. Dairy Sci. 93:644-655. https://doi .org/10.3168/jds.2009-2295.

Wheelock, J. B., A. J. La Noce, M. D. O'Brien, S. R. Sanders, R. J Collier, L. H. Baumgard, and R. P. Rhoads. 2008. The effect of heat stress and exogenous bovine somatotropin on expression of genes associated with hepatic gluconeogenesis in lactating dairy cows. J. Dairy Sci. 91(E Suppl. 1):455. Abstr.

Wilson, S. J., R. S. Marion, J. N. Spain, D. E. Spiers, D. H. Keisler, and M. C. Lucy. 1998. Effects of controlled heat stress on ovarian function of dairy cattle. 1. Lactating cows. J. Dairy Sci. 81:21242131. https://doi.org/10.3168/jds.S0022-0302(98)75788-1.

Wiltbank, M., H. Lopez, R. Sartori, S. Sangsritavong, and A. Gümen. 2006. Changes in reproductive physiology of lactating dairy cows due to elevated steroid metabolism. Theriogenology 65:17-29. https://doi.org/10.1016/j.theriogenology.2005.10.003. 
Wise, M. E., D. V. Armstrong, J. T. Huber, R. Hunter, and F. Wiersma. 1988. Hormonal alterations in the lactating dairy cow in response to thermal stress. J. Dairy Sci. 71:2480-2485. https://doi .org/10.3168/jds.S0022-0302(88)79834-3.

Wolfenson, D., I. Flamenbaum, and A. Berman. 1988a. Dry period heat stress relief effects on prepartum progesterone, calf birth weight, and milk production. J. Dairy Sci. 71:809-818. https://doi .org/10.3168/jds.S0022-0302(88)79621-6.

Wolfenson, D., I. Flamenbaum, and A. Berman. 1988b. Hyperthermia and body energy store effects on estrous behavior, conception rate, and corpus luteum function in dairy cows. J. Dairy Sci. 71:34973504. https://doi.org/10.3168/jds.S0022-0302(88)79956-7.

Wolfenson, D., B. J. Lew, W. W. Thatcher, Y. Graber, and R. Meidan. 1997. Seasonal and acute heat stress effects on steroid production by dominant follicles in cows. Anim. Reprod. Sci. 47:9-19. https:/ /doi.org/10.1016/S0378-4320(96)01638-7.

Wolfenson, D., Z. Roth, and R. Meidan. 2000. Impaired reproduction in heat-stressed cattle: Basic and applied aspects. Anim. Reprod.
Sci. 60-61:535-547. https://doi.org/10.1016/S0378-4320(00)00102 -0 .

Worstell, D. M., and S. Brody. 1953. Comparative physiological reactions of European and Indian cattle to changing temperature. In: Environmental Physiology and Shelter Engineering XX, Research Bulletin 515, Missouri Agricultural Experiment Station, University of Missouri, Columbia, MO.

Yamamoto, S., J. A. McLean, and A. J. Downie. 1979. Estimation of heat production from heart-rate measurements in cattle. Br. J. Nutr. 42:507-513

Yousef, M. K. 1985. Stress Physiology in Livestock. Vol. 1. CRC Press, Boca Raton, FL.

\section{ORCIDS}

R. J. Collier () https://orcid.org/0000-0002-1552-9711

A. E. Stone 누 https://orcid.org/0000-0001-5687-3394 